\title{
SELIDBE I SUŽIVOT NA LJETNIM STANOVIMA
}

\author{
Marijeta RAJKOVIĆ \\ Filozofski fakultet Sveučilišta u Zagrebu \\ Odsjek za etnologiju i kulturnu antropologiju \\ Ivana Lučića 3, 10000 Zagreb
}

\section{UVOD}

Tstražujući tradicijsko gospodarstvo tema sezonskih migracija, ${ }^{2}$ za čiji je oblik u hrvatskoj literaturi uvriježena sintagma selidbe na ljetne stanove, nametnula se kao neophodna za istraživanje istoga, kao i razumijevanja načina tradicijskoga života i kulture. Naime, iz primorskoga pojasa (primjerice: Sv. Ilije, Sibinja, Cupine, Bunice, Špalja, Sv. Jelene, Pijavice) stanovništvo je u proljeće selilo prema planinskim pašnjacima na primorskoj strani Velike Kapele, na područja oko 500 do 600 metara nadmorske visine (primjerice: Šušanj, Kosova Buljima, Vrataruša). U jesen su se selili u Primorje gdje su provodili vrijeme do proljeća. No ovo je područje specifično po tome što su na višim nadmorskim visinama (spomenuti Šušanj, Vrataruša, Kosova Buljima) već živjeli stalni stanovnici, koji su se katkada selili na još više nadmorske visine na oko 800 do 900 metara (Alan, Podbilo, Krivi Put); pored njih na te iste visine selili su i pojedini Primorci. Tijekom 20. stoljeća seobe su ovisile od obitelji do obitelji, tako da su neki selili na jednu etapu (s prve na drugu ili s prve na treću), a neki na dvije (s prve na drugu, pa s druge na treću), dok neki uopće nisu selili, odnosno stalno su stanovali na drugoj ili trećoj etapi (usporedi tablicu 1).

$\mathrm{Na}$ geografskom području koje pokrivam ovim radom, prema mojim saznanjima, do sada nitko nije istraživao sezonske migracije, dok su za susjedna područja, točnije područje sjevernog Velebita, u starijoj etnološkoj i antropogeografskoj literaturi te seobe opisane ponajviše kao izdizi stoke na ljetne stanove. Unatoč tome što je na početku rada uobičajeno dati kritički prikaz literature o pojedinoj problematici, odlučila sam to napraviti tek u zaključku upravo iz razloga što smatram da se podaci iz literature o susjednim područjima ne mogu u cijelosti komparirati. Naime, prilikom nestrukturiranih intervjua, odnosno rekognisciranja terena za pripremu upitnice za temu migracija došla sam do spoznaje da migracije stanovništva nisu bile isključivo izdizi stoke i da bih dobila vrlo upitne podatke da sam se ograničila samo na tu problematiku. Razlozi seljenja Primoraca bile su ispaše blaga (goveda i ovce), ali i uzgoj svinja, obrađivanje zemlje (motičarstvo), prikupljanje sijena, te u manjoj mjeri ispaša pčela. Stoga sam ovo istraživanje usmjerila na sveukupan način života na koji su utjecale posljedice migracija. Cilj je ovoga rada bio utvrditi potisne i privlačne faktore selidaba, život na ljetnim stanovima (nastambe, interakcijske odnose između migratornog ${ }^{3}$ stanovništva (Primoraca) i domicilnog ${ }^{4}$ stanovništva (stalnih stanovnika viših nadmorskih visina). Osim navedenoga, postojale su i specifične dnevne migracije za potrebe školovanja, izvora prihoda, provođenja vjerskih praksi te sahrana. Budući da je istraživanje usmjereno i na saznanja o etnokulturnom oblikovanju i porijeklu Bunjevaca, za rasvjetljavanje ove problematike nastojala sam ispitati uzroke

1 Rad je u neznatno izmijenjenoj varijanti objavljen u Senjskom zborniku 32 iz 2005. godine pod naslovom: Sezonske migracije na području Krivog Puta: tradicija u recentnoj povijesnoj perspektivi, str. 273-348.

2 Sezonska migracija oblik je privremene migracije, povezane sa zapošljavanjem u drugom mjestu koji se obavljaju u određenom godišnjem dobu, tj. u "sezoni" (usporedi s Heršak, 1998: 250).

3 Migrant: osoba koja se seli, odlazi, vraća se; sudionik u procesu prostorne pokretljivosti stanovništva (ibid. 146147).

4 Domicilno stanovništvo: od lat. dömǔčllǐum, "stan, dom, < dŏmus, "dom, kuća”, izraz za ljude koji imaju trajno prebivalište u nekom mjestu (usp. ibid. 42). 
ovakva specifičnoga načina života te uočila kako su se od privremenih ljetnih naselja formirala pojedina stalna naselja, čak i s osnovnom školom. Kroz rad se provlače simbolične granice između dviju zajednica, odnosno strategije autoidentifikacije kojima se migratorno i domicilno stanovništvo razgraničuje jedno od drugoga. Navodi se simbolični inventar koji pripadnici svake skupine ističu kao razlikovni u odnosu na Druge, koji unatoč životu na istim prostorima percipiraju međusobnu različitost.

$\mathrm{Na}$ kraju rada ukazujem na ulogu etnoloških istraživanja u revitalizaciji ovog depopuliranoga kraja kroz oblike ruralnog turizma, posebice prikaza života na ljetnim stanovima.

\section{2. ŽIVOT NA PODRUČJU KRIVOGA PUTA}

Z a geografski prostor koji pokriva ovaj rad u tekstu ću upotrebljavati sintagmu područje Krivoga Puta. Taj naziv odabran je iz razloga što stanovništvo iz svih naselja i zaselaka gravitira Krivome Putu (primjerice ondje se nalaze trgovina i osnovna škola), a osim toga stanovnici ovoga područja se i identificiraju s Krivim Putem. Prema službenoj terminologiji (popisima stanovništva) Krivi Put danas je samo jedno od naselja. ${ }^{5}$ Na prostoru koje obuhvaćam ovim radom tijekom moga istraživanja postojalo je pet naselja: Krivi Put (sa 58 stanovnika), Podbilo (sa 46 stanovnika), Veljun Primorski (sa 91 stanovnikom), Alan (sa 11 stanovnika) te Mrzli Dol (sa 27 stanovnika). Ova naselja imala su tijekom 20. stoljeća mnogo zaselaka koji su zbog iseljavanja stanovništva postepeno nestajali tijekom druge polovice 20. stoljeća. ${ }^{6}$ Osim u mjesta koja su ucrtana u karte, Primorci su selili u lokalitete do kojih se moglo doći samo pješice tzv. kozjim stazicama. Dakle, ta naselja nisu imala ceste, struju ni vodu, ${ }^{7}$ odnosno bila su bez infrastrukture.

U njima je živjelo nekoliko obitelji ili tek jedna obitelj, kako se saznaje iz naracija Zlatka Tomjanovića Kaića za okolicu Alana: Vodina Bukova - vodin stan, tamo je bila jedna kuća i oni su dolazili gore svake godine. Onda Lisičina Vodina ili draga (na karti označeno kao Lisca) na putu prema Sibinju jedna familija, onda Skalina. Ovakav odabir objasnio je Petar Tomljanović Jukša iz Krivoga Puta: Bilo je puno naroda, nije se imalo di selit. Selilo se di je bilo mista. Nije bilo odredeno gdje će ljudi selit, već je ovisilo o tome gdje tko ima zemlju i šume. Nisu selili na tude. ${ }^{8} \mathrm{U}$ takvim naseljima pojedine obitelji živjele su čitavu godinu. Ta su naselja najčešće bila na oko 500 do 600 metara nadmorske visine.

Pomoću sljedeće tablice nastojala sam prikazati s koje su nadmorske visine stanovnici selili na koja područja. Ova je tablica tek pregledna iz razloga što su migracije bile, najblaže rečeno, nepravilne. Primjerice, iz Bunice je jedna obitelj selila u Vratarušu (na oko 600 m nadmorske visine), druga u Špalje (u Podbilo na oko $750 \mathrm{~m}$ nadmorske visine), treća u Zamalić (na Alan, na oko $900 \mathrm{~m}$ nadmorske visine). U istom dijelu godine, dok su jedni sa $100 \mathrm{~m}$ nadmorske visine selili na $600 \mathrm{~m}$ nadmorske visine, poneki koji su stanovali na 600 m nadmorske visine selili su na 900 m nadmorske visine. Primjerice iz Šušnja u Kaićevu Gredu ispod Alana.

Kako bih prikazala bogatstvo migracija navest ću konkretne podatke koje sam prikupila. Ukoliko se na tablici pogleda smještaj pojedinoga naselja i usporedi s navedenim podacima, može se dobiti vizualan dojam migracijskih mobilnosti.

Detaljnije vidi u prilogu Blaženke Ljubović u ovoj monografiji.

6 Za detaljniji pregled migracija na području Krivoga Puta tijekom 20. stoljeća vidi rad M. Rajković u ovoj monografiji te Senjski zbornik 31 iz 2004. godine.

7 Za detaljniji uvid o opskrbi vodom na području Krivoga Puta vidi rad D. Birt i M. Dronjića u nastavku ove monografije.

8 Anka Butković Matićeva, Alan. 


\begin{tabular}{|c|c|c|c|c|c|c|c|c|c|c|}
\hline \multicolumn{11}{|l|}{$\begin{array}{l}\text { Nadmorska } \\
\text { visina }^{1}\end{array}$} \\
\hline $900-1000 \mathrm{~m}$ & $\begin{array}{l}\text { Alan }^{2} \\
\text { Zamalić }\end{array}$ & & & Bilo & & & & & & \\
\hline $800-900 \mathrm{~m}$ & & & $\begin{array}{l}\text { Čupića } \\
\text { glavica }\end{array}$ & & & $\begin{array}{l}\text { Krivi } \\
\text { Put }^{3} \\
\text { Śpalji }\end{array}$ & & & & $\begin{array}{l}\text { Šojatski } \\
\text { Dolac }\end{array}$ \\
\hline $700-800 \mathrm{~m}$ & & & & $\begin{array}{l}\text { Podbiló }^{4} \\
\text { Žuljevići }\end{array}$ & & & & & $\begin{array}{l}\text { Veljun } \\
\text { Primorski }\end{array}$ & \\
\hline $600-700 \mathrm{~m}$ & $\begin{array}{l}\text { Butković } \\
\text { Dolac }^{6} \\
\text { Vargin } \\
\text { stan }\end{array}$ & & & & & & & Francikovac & & \\
\hline $500-600 \mathrm{~m}$ & Šš̌anj ${ }^{7}$ & $\begin{array}{l}\text { Tomišina } \\
\text { draga }\end{array}$ & $\begin{array}{l}\text { Kosova } \\
\text { Buljima }^{8}\end{array}$ & Vrataruša ${ }^{9}$ & & & Klaričevac & & & \\
\hline $400-500 \mathrm{~m}$ & & & & & & & & & & \\
\hline $200-300 \mathrm{~m}$ & $\begin{array}{l}\text { Vodna } \\
\text { Draga }\end{array}$ & & & & & & & & & \\
\hline $100-200 \mathrm{~m}$ & Sv. Ilija & Sibinj & Cupina & Bunica & Špalji & $\begin{array}{l}\text { Sv. } \\
\text { Jelena }\end{array}$ & Pijavica & & & \\
\hline
\end{tabular}

Tablica 1: Prikaz istraženih naselja. Naselja sam nastojala prikazati kao što su smještena u prostoru. Masnijim slovima označena su naselja u kojima su živjeli stalni i sezonski stanovnici. Irradila M. Rajković.

Biljeske uz tablicu

1 Zbog bolje preglednosti nisam precizirala nadmorske visine pojedinih naselja.

2 Naselju Alan su u 20. stoljeću pripadali zaseoci: Alan, Brina, Butković Dolac, Cigići, Klanac Alanski, Rupa, Vrtlina, Zamalić (usp. M. Korenčić, 1979:603).

3 Pod naselje Krivi Put su u 20. stoljeću pripadali zaseoci: Anići, Gorica Krivoputska, Krivi Put, Longovac, Nikolići, Šašina, Šojatski Dolac, Špalji, Špinići, Zekanovići (ibid. 603).

4 Naselju Podbilo također je pripadalo više zaselaka, u popisima stanovništva za 20. stoljeće nalaze se: Cupići, Matić-Gaj, Murtići, Panjići, Plemići, Podbilo, Šimerići, Šolići, Tomići, Žuljevići (ibid. 604).

5 Naselju Veljun Primorski su u 20. stoljeće pripadali zaseoci: Brezica, Burići, Donji Veljun, Francikovac, Francikovac-Matići, Gornji Veljun, Kuljići, Lopci, Lukci, Marinovići, Milčcići, Mlići, Petrovo, Rončevići, Šabani, Škopci, Veljun Primorski, Zečevi (ibid. 605).

6 Stalno je bilo naseljeno šest do osam kuća prema Zlatku Tomljanoviću Kaicu, Milanu Prpiću Brkcu, Nadi Prpić Grgaici. Razlika u broju kuća je stoga što se podaci odnose za razdoblje od pedesetak godina, a ovise o tumačenju svakog pojedinog kazivača.

7 Stalno je bilo naseljeno šest kuća prema Zlatku Tomljanoviću Kaiću, devet kuća prema Milanu Prpiću Brkcu, Nadi Prpić Grgaici.

8 Stalno je bilo naseljeno šest do osam kuća prema Milanu Tomljanoviću Livaku, Zlatku Tomljanoviću Kaicu, devet kuća prema Milanu Prpiću Brkcu, Nadi Prpić Grgaici. Prema kazivanjima ovdje nije bilo sezonskih stanovnika.

$9 \quad$ Stalno su bile naseljene četiri kuće prema Milanu Tomljanoviću Livaku šest kuća prema Zlatku Tomljanoviću Kaiću, trinaest kuća prema Milanu Prpiću Brkcu, Nadi Prpić Grgaici, Miri Ostović Šare. Prema kazivanjima ljeti je ovdje ponajviše ljudi selilo iz Bunice.

Iz Sovine Drage selili su u:

- Podbilo (u Žuljeviće), jedna obitelji iz koje su tridesetih godina 20. stoljeća nastale četiri obitelji),

- u Podbilo (u Sovin stan), jedna obitelj iz koje su nastale dvije obitelji, ${ }^{10}$

- u Alan (u Zamaliće), obitelj Tomljanović. ${ }^{11}$

9 Anka Šolić Tutanova, Podbilo.

10 Anka Šolić Tutanova.

11 Zlatko Tomljanović Kaić, Šušanj; Anka Šolić Tutanova. 
Iz Bunice - na Vratarušu ${ }^{12}$

u Zamalić (Alan), ${ }^{13}$

iz Komara (dio Bunice) na Alan (Vrtlinu), ${ }^{14}$

obitelj Motike u Špalje. ${ }^{15}$

Iz Špalja (̌́paljeve kose $)^{16}$ - u Špalje (Krivi Put) ${ }^{17}$

Iz Šušnja - u Kaićevu gredu (ispod Alana), jedna obitelj - kasnije tri obitelji, ${ }^{18}$

Bekin dolac (ispod Čupić glavice, Alan), obitelj Brkičevi,

u Francikovac, obitelj Tomljanović. ${ }^{19}$

Iz Sv. Ilije - Zamalić (Alan) ${ }^{20}$

Sibinja - Zamalić (Alan), ${ }^{21}$

- obitelj Butković prema Alanu, 22

pod Omar (iznad Butković dolca prema Zamaliću), četiri obitelji, ${ }^{23}$ u Šušanj. ${ }^{24}$

Iz Kosove Buljime - u Grgaicin stan na Bekin Dolac do otprilike 1950-ih. ${ }^{25}$

Iz Vuketske Drage - na Vrtlinu (Alan) (obitelj Vukelići) do početka 1900., nakon toga su trajno ostali ovdje. ${ }^{26}$

Iz Sv. Jelene - na Škicin stan (između Vrataruše i Klaričevca), obitelj Špalji, kasnije su nastale dvije obitelji koje su stanovale u jednoj kući ${ }^{27}$ do otprilike 1950.,

u Klaričevac, ${ }^{28}$

u Špalje (na Krivom Putu), ${ }^{29}$

u Špinjiće (prema Francikovcu kod Šojatskog Dolca)..$^{30}$

Iz Cupine u Klaričevac, ${ }^{31}$ - u Cupiće (Podbilo). ${ }^{32}$

Iz Pijavice u Klaričevac, ${ }^{33}$

- u Špiljiće. ${ }^{34}$

12 Anka Butković Matićeva, Alan; Anka Šolić Tutanova, Milan Prpić Brkac, Nada Prpić Grgaica, Kosova Buljima; Mira Ostović Šare, Bunica; Milan Tomljanović Livak, Bunica.

13 Zlatko Tomljanović Kaić, Milan Tomljanović Livak.

14 Milan Prpić Brkac.

15 Mladen Šojat Bilin, Senj.

16 Milan Prpić Brkac.

17 Anka Šolić Tutanova, Luka Krmpotić Brnde, Veljun; Mile Špalj Kebin, Krivi Put; Ruža Prpić Apelova, Mrzli Dol.

18 Zlatko Tomljanović Kaić, prestali su seliti 1941. godine budući da im je u ratu zapaljen stan. Kasnije su samo odlazili obrađivati zemlju.

Mladen Šojat Bilin, Milan Šojat Colaš, Francikovac.

20 Zlatko Tomjanović Kaić.

Milan Tomljanović Periša, Alan; Zlatko Tomjanović Kaić, Šušanj.

22 Tome Špalj Cucin, Krivi Put.

3 Milan Tomljanović Periša.

24 Milan Tomljanović Livak.

Zlatko Tomjanović Kaić.

Anka Butković Matićeva.

Zlatko Tomjanović Kaić.

Milan Prpić Brkac, Nada Prpić Grgaica, Kosova Buljima; Tome Špalj Cucin, Mladen Šojat Bilin.

Mladen Šojat Bilin, Mladen Prpić.

Milan Tomljanović Livak.

Milan Prpić Brkac, Nada Prpić Grgaica.

Petar Tomljanović Čona, Podbilo.

Nada Prpić Grgaica, Milan Prpić Brkac, Mladen Šojat Bilin.

Milan Tomljanović Livak. 
Iz Vrataruše - na Francikovac, ${ }^{35}$ obitelj Tomljanović - stalno doselila.

Iz Senjske Drage - na Francikovac, jedna obitelj početkom 20. stoljeća. ${ }^{36}$

Iz Klenove Kose - u Podbilo, dvije obitelji - Jojini i Tomljanovići- Dadići. ${ }^{37}$

Kao što sam spomenula, zbog depopuliranosti područja za neke sam lokalitete podatke dobivala usmenom predajom, tako da kazivači uglavnom nisu znali točno precizirati koliko je ljudi i kada selio.

U pojedinim naseljima domicilno stanovništvo živjelo je u jednim zaselcima, a migratorno u drugim. Primjerice, na području Alana zaselci Cupići i Tomići imali su stalne stanovnike, a Primorci su najviše selili u Zamalić. No prema navodima kazivača stanovništvo je uglavnom bilo izmiješano. Jedna zanimljivost koju sam otkrila tek u krajnjoj fazi sinteze građe upravo je oblik stanovanja u tzv. zadružnim obiteljima na ljetnim stanovima. Primjerice kada su u obitelji bila dva sina i nakon što su oni formirali svoje obitelji u Primorju svatko je stanovao u vlastitoj kući dok su na planinama svi boravili u roditeljskom ljetnom stanu. Tako je Zlatko Tomjanović Kaić rekao: Mi smo imali stan kod Alana zove se Kaićeva greda i tu su ljeti selili svi, sričevi, tatin brat, svi smo bili u jednoj kući. Jedna šternja je bila.

Da bi se razumjeli potisni i privlačni faktori sezonskih migracija odlučila sam istražiti razlike u načinu života i osnovne izvore prihoda Primoraca te stanovnika viših predjela ovog područja. Pod područje Krivi Put spadala su i primorska sela, dakle sela uz obalu. ${ }^{38}$ Primjerice to su: Pijavica, Špalji, Bunica, Sibinj, Šolići, Sv. Jelena, Sv. Ilija te područje prema naseljima Krivom Putu, Podbilu i Alanu. Izvori prihoda za Krivopućane na višim nadmorskim visinama, kao i Primorce, bili su poljoprivreda i stočarstvo, no s razlikama. Primorci su se vrlo malo bavili zemljoradnjom u Primorju, sadili bi malo krumpira i povrća, žitarice ne znam da je 'ko tu sija. Sv. Jelenu su do 1916. zvali mala Dalmacija, zato što je imala vina, al' je onda floksera uništila lozu. U ostalim mjestima nije bilo razvijeno vinogradarstvo, tek nešto malo u Bunici. Držali bi dvije do četri krave, kolko je ko mogao, onda priko ljeta odgoji svinje, dvadesetak ovaca i radili ko proleteri vani. To su doma sve žene delale. Ljudi dođi doma za košnju, ${ }^{39}$ rekao je Tome Špalj Cucin. Ovi izvori prihoda također nisu bili dostatni", te su muškarci i s ovih prostora odlazili na privremene radove. Međutim, za razliku od Krivopućana kojima je rad u šumama bio primaran, Primorci su bili i obrtnici, što se vidi i iz kazivanja Milana Tomljanovića Livaka: Najviše su išli na teren, radili su za plaće. Muškarci su okolo radili. Delali po vani kao obrtnici, većinom zidari. Dolazili bi kući jednom mjesečno i kupili stvari.

Na prostorima od otprilike 500 do 600 metara nadmorske visine bilo je nekoliko većih zaselaka (već spomenuti Šušanj, Kosova Buljima, Vrataruša), no stanovnici i te zaselke nazivaju Primorjem, ali smještenim na planinu: Moje selo Šušanj spada pod Primorje, al' to su zvali planina. ${ }^{40}$ Kazivači su također navodili razlike između, "pravog" Primorja i života na "planini" na oko 500 metra nadmorske visine. Mi ova sela Vrataruša, Kosova Buljima i Šušanj smo imali konje. To je bio već malo drugi život nego je bia sasma dole. Oslobodi me Bože. Imali smo konje, krave, ovce, koze, magare. Sibinj je držao mule, jer su mule najotpornije. Dole je sve kamen. One su bile skuplje neg konj, cijelo Podgorje je držalo mule, bašzbog terena. ${ }^{41}$ Primorci su imali više krava (dvije do četiri) od Krivopućana iz razloga što su Primorke svakodnevno nosile prodavati mlijeko u Senj, te deset do dvadeset ovaca. No svaka obitelj neizostavno je imala magarca ili mulu ili po jedan par. $\mathrm{O}$ važnosti tih teglećih životinja govore u prilog naracije Petra Tomljanovića Jukše: Imali smo drvene samare, najviše smo gonili na njima, na tovaru, muli i magarcu seli gore. Nama su brda bila, nisi moga nista drugo nego samar, nisu kola mogla. Samar, magarac ili konj i motika, to je nama bilo glavno.

35 Mladen Prpić.

36 Milan Šojat Colaš.

37 Mladen Šojat Bilin.

38 O promjenama administrativnih granica tijekom 19. i 20. stoljeća vidi u prilogu Blaženke Ljubović u ovoj monografiji.

39 U Vrataruši, Šušnju i Kosovoj Buljimi vrijeme sjenokoše bilo je od 15. lipnja do 15. srpnja.

40 Milan Prpić Brkac.

41 Nada Prpić Grgaica, Milan Prpić Brkac. 
Svi kazivači samoinicijativno su isticali simboličke granice prema drugim skupinama stanovnika. Krivopućani su bili puno bogatiji nego mi ovde jer su imali više zemlje, više krumpira, žita, svega. A mi smo vako. Mi smo imali male parcele, kazao je Ivan Vukelić Mikula. Anka Butković Matićeva pak smatra: Primorci su imali sve 'ko i mi samo su živjeli na dvi strane. Vamo priko ljeta, a doli su imali namješteno 'ko svi ljudi. Možda još i bolje jer su živjeli uz grad. Milan Prpić Apel iz Mrzloga Dola naveo je: Bili su veći jadnici nego mi, jer su se morali selit, a drugo sve isto ko mi.

\subsection{SELIDBE NA LJETNE STANOVE}

$\mathrm{P}$ ojedine primorske obitelji posjedovale su njive i livade na višim nadmorskim visinama; odlazile ondje prema potrebi raditi, no nisu nužno tamo i selili. Kada bi nešto radili prespavali bi kod ovih koji su selili. Jer to je dugačak put, a ujutro se rano počimalo radit, kosit, orat. Znali su bit gore po pet, šest dana. To je bilo sve redom, recimo u Francikovcu, iza Vratnika, i preko dva sata oda se išlo kosit litnja doba. Onda si neko napravi stan za leć, da ne ideš kući. To napravi od drveta na dvi vode ili polukružno zakreni. Gori pokri, nasjeci jelovine pa napravi šimle. ${ }^{42}$ No ovakvi priručni stanovi bili su rijetkost.

Nisam zabilježila podatak da su svi stanovnici jednoga sela selili u drugo selo na višoj nadmorskoj visini. Najčešće nisu selile obitelji nego samo pojedini ukućani. Primjerice kada su djeca završila škole i pronašli posao prestali su seliti, dok su njihovi roditelji i dalje selili. Did i baba su u Sibinju živili i imali su zemlju na Alanu. Tamo je plodna zemlja. Ćaća je radio, pa su baba i did išli gore sami. Mi dica i mama smo svaki dan išli gori i nosili stvari doli, a inače smo bili doli nismo selili. ${ }^{43}$ Mira Ostović Šare kazala je: Moj tata je bio jedini koji nije selio gore dolje, njegovi roditelji jesu. Tata je bio od rijetkih ljudi koji je krenuo u školu $i$ imao državnu službu. Inače do rata svi smo bili nepismeni. Selidbe su uglavnom bile individualne, a njihov razlog objasnio je Zlatko Tomjanović Kaić: Naša familija doli nije imala puno zemlje, a gori je. Druga familija je više zemlje imala doli, onda im je bolje ostat doli. A nama je tamo bila zemlja za sve. U šumu (na Alanu op. a.) se išlo na posa. U jesen kad bi sve pobrali išli smo nazad u Šušanj.

\subsection{SELIDBE NA BILO}

P ojedinci su posjedovali zemlju i preko planine Bila, koje se proteže iznad Podbila. Međutim ovih selidbi prisjećaju se rijetki pojedinci. Samo je Marko Pavelić Mijatina, rođen 1917. godine u Podbilu, selio preko Alina bila: Mi smo gore preko Bila išli na ljetne stanove. Tamo su bile livade koje smo kosili. Na tri miseca smo išli tamo i sadili krumpir, žito i kupus. Cijela obitelj je gore selila. Bilo je gore više stanova, al su bili daleko jedan od drugoga. Nismo gore imali šterne, već snig u jamama. Ja sam presta selit kad sam bia treći razred osnovne škole (oko 1929. godine, op. a). Mi smo zadnji selili jel više ljudi nisu bili zainteresirani.

Ovu selidbu potvrdila je samo kazivačica Anka Šolić Tutanova, također iz Podbila: Mijatina je imo stan gore, pa još tu jedan susjed. Tako isto natkrito. Stavi one dvi ili četri to se kaže soja, pa gore nabacaj sjena ili pokri nečim. Tolko da se može po noći uvuć da ne mora ići kući kad kosi ili radi šta. Može i vatru naložit, nije to tak bilo nisko da može izgorit, al se pazilo. To nabacaj malo drveća ili što. Sve od drveta. Nije bilo od kamena. Vraga, ko će. Nisam ja nikad selila tamo, samo sam znala prolazit. Mijatina je često znao bit gore, pa ga sretni. Govorili su da su njegovi prije gore selili s kravama liti kad bi bila velika suša. To je prvo bilo, jošsam ja mala bila. Ostali kazivači nisu znali za te selidbe, ali ih je većina iz Podbila odlazila na Bilo kositi travu tijekom prve polovine 20. stoljeća.

\footnotetext{
42 Luka Krmpotić Brnde.

43 Milan Tomljanović Livak.
} 


\subsection{RAZLOZI MIGRACIJA}

Dotisni faktori ljetnih odlazaka Primoraca na više nadmorske visine bili su gospodarske prirode, npr. svi 1 su kazivači navodili obradive površine na planinama, livade za ispašu stoke te košnju trave (odnosno prikupljanje sijena i šušnja (lišća) za zimsku prehranu blaga) i ispašu pčela. Gori je ipak kolko tolko planina na nekih 500 metara nadmorske visine i zemlja je bar nešto davala, a ova u Primorju nije davala ništa. To je plitka pjeskovita zemlja. A gore su ipak bile i rose, pa od toga se iživilo. ${ }^{44}$

Stoka je, odnosno kako kazivači kažu blago, išla na ispašu u planinu, budući da je u Primorju kamenjar, odnosno nema dovoljno trave i temperature su previsoke. Na planini je pogodnija klima i plodna zemlja. Svako je ima nešta blaga pa ga je gonio ovdje na pašu jer doli je jako sunce pa sve ispeče. Doli bi se pokosilo, a ovde bi svako ima malo zemlje za obradit pa je blago trebalo i da zemlju nadubri jer sav se dubar gonio na tovaru, navela je Anka Šolić Tutanova. Poneki kazivači poput Milana Tomljanovića Periše kao primarni razlog selidbe navodili su zemljoradnju i gnojenje oranica: Oni su gore oko Alana imali zemlju onda da ne bi gonili dubar, preselilo bi se sve i blago $i$ oni liti gore.

\subsection{ORGANIZACIJA SELIDBE NA LJETNE STANOVE}

$\mathrm{V}_{\mathrm{p}}$ rijeme početka selidbi na ljetne stanove ovisilo je o odluci pojedinaca. U početku su odlazili prema potrebi dan, dva obrađivati zemlju, nakon što su preselili blago netko je gore morao stalno boraviti, no svi kazivači isticali su da je to ovisilo o klimatskim prilikama određene godine. Zabilježila sam da su selidbe započinjale u ožujku, ${ }^{45}$ oko 15 . travnja, nekad budi snijega do 1. svibnja pa ne možeš ništa dok je snjeg, ${ }^{46}$ početkom svibnja, ${ }^{47}$ tijekom svibnja ${ }^{48}$ oko 1 . lipnja ili do Duhova, ${ }^{49}$ nakon što se u Primorju pošišaju ovce. ${ }^{50}$ Seobe su trajale po nekoliko dana. Prije samog preseljenja trebalo je napraviti pripreme: Ako nekog nema nekoliko meseci u kući, normalno da trava naraste. Onda su dolazili u proliće na dan, dva, čistit, sadi. Isli svakih pet, šest dana doli gori, pomalo nosili stvari. ${ }^{51}$ Did bi ima kravu, jednu ili dvi mule, svinju. Kokoši bi baba svezala u neku kištricu i svaki dan po malo goni gore dok bi se sve preneslo. ${ }^{52}$

Bilo je i slučajeva kada obitelj nije odlazila zajedno, već su selidbe bile uvjetovane gospodarskim radovima. Ako su vremenske prilike bile povoljne, oko Jurjeva su (23. travnja) selili blago, a kad je ošlo blago morala su i dica jer moro je neko blago čuvat, ${ }^{53}$ muškarci su išli orat zemlju oko 1. svibnja, a zatim žene sijat, pomalo posle svi ostali, kada je dolazila košnja dolazili su svi. ${ }^{54}$

Stanovnici koji su stalno boravili na oko 500 do 600 metara nadmorske visine kazali su da su njima te selidbe bile jako interesantne i da su ih pratili sa zanimanjem. Stoga ću navesti nekoliko komentara: Dva dana oni su selili gori, onda bi rekli mi: 'Evo prođoše Primorci. Reci: Preseliše Primorci.' Kad bi ih pitali: 'Kud idete?' 'Selim u planinu.' rekli bi. Jer odoše od mora u brdo gore. ${ }^{55}$ Mi bi rekli: 'Evo Primoraca, evo koza i ovaca. ${ }^{56}$

4 Milan Tomljanović Livak.

45 Milan Prpić Apel.

46 Petar Tomljanović Jukša.

47 Mladen Šojat Bilin.

48 Anka Butković Matićeva, Milan Tomljanović Periša, Milan Tomljanović Livak, Milan Prpić Brkac.

${ }^{49}$ Ovce se najčešće šišalo za katolički blagdan Duhova, što je opjevano i u bećarcu: Na Duhove šišaju se ovce, bješte cure makar za udovce! kojeg mi je otpjevao Milan Tomljanović Periša.

50 Tome Špalj Cucin, Anka Šolić Tutanova.

51 Milan Prpić Brkac, Mile Špalj Kebin, Krivi Put.

52 Milan Tomljanović Livak.

53 Više o organizaciji čuvanja blaga vidi u prilogu M. Rajković o stočarstvu u nastavku ove monografije.

54 Milan Prpić Apel.

55 Milan Prpić Brkac.

56 Tome Špalj Cucin, Petar Tomljanović Jukša. 
Tijekom svih razgovora Krivopućani su isticali siromaštvo, nepovoljne životne uvjete i primoranost na migracije. Budući da su stanovali na dvije lokacije, Primorci su većinu osobnih stvari i kućnog inventara nosili sa sobom. U prilog tome Anka Butković Matićeva navodi: Nije bilo ni gore ni dolje, imali su tu nužno. Nosili su hranu, posuđe, škaf za pranje veša, razne sitne kućne potrepštine. Nosili su sve tekstilne predmete, primjerice posteljinu i odjeću, iz razloga što su miševi sasjekli sve što su ondje ostavili preko zime. Kazivač Milan Tomljanović Periša sječa se da su: Iz Sibinja gonili suhi dubar od koza i ovaca gore, onu prašinu što bi bilo lako, metni u vré́e i goni na tovaru i mulama.

\subsection{SELIDBE PČELA ${ }^{57}$}

Cobzirom na nadmorske visine u Primorskim je selima gotovo svaka kuća imala pčele, na nadmorskoj visini od oko 500 metara u prosjeku svako treće kućanstvo bavilo se pčelarstvom, dok za područje na oko 800 metara nadmorske visine uzgoj pčela pronalazimo tek u tragovima. Razlog tome su opet geografske odlike terena i klimatske prilike, ponajviše duge zime. Ovi razlozi bili su uzroci selidbe pčela na ispašu na više nadmorske visine.

Pčele su bile u Primorju do svibnja kada ondje cvjeta kadulja, a tijekom lipnja Primorci su selili pčele na Planine na vrisak. Pčele su tu boravile do u kasnu jesen, kada su ih opet selili u Primorje. Nakon što su Primorci početkom druge polovice 20. stoljeća masovno selili u Senj i prestali seliti na ljetne stanove, nastavljali su se baviti pčelarstvom u Senju te ljeti seliti košnice na ljetne stanove.

\section{3. ŽIVOT NA LJETNIM STANOVIMA}

\subsection{NASTAMBE ${ }^{58}$}

U ovom poglavlju namjera mi je ukazati na sličnosti i razlike u kulturi stanovanja domicilnog i migratornog stanovništva. Stanovi su bili lošiji. Neko je ima bolju kuću, neko lošiju, bilo je jadnih i bijednih kuća i stanova, a bilo je i boljih kuća nego u Primorju. Kako je 'ko mogao. ${ }^{59}$ Prevladavali su odgovori da su kuće od domicilnog stanovništva bile bolje: Ovi koji su gore bili stalno, oni su imali malo veće kuće. Štala je bila malo veća jer su imali i više blaga, a ovi koji su selili toliko da ljeto prode. ${ }^{60}$ Tome Špalj Cucin i Petar Tomljanović Jukša kazali su: Kuće od ljudi koji su stalno gore boravili su čvršć gradene zbog zime. Mora bit da ne puše i da ne kaplje, i štalice su morale biti jer tamo zapada tri metra snijega, a ove za litnja doba nema veze. Nisu ni imali od čega napravit. Oni se nisu privikavali na zimu. Oni su dolje imali bolje kuće nego ovi gore. Rade su selili doli, bojali su se da im vuk ne zakolje ovcu. Jedan did koji je selio je priča: Neću ja slušat kad će vuk zavijat na vidalicu. ${ }^{11}$

Zabilježila sam i nekoliko primjera kada su Primorci selili, ali nisu imali stana već su kod nekog boravili. To je primjerice vidljivo iz naracije Anke Šolić Tutanove: Bili smo u Žuljevićima, kod jednih ljudi u staroj kući, onda u Podbilu kod drugih ljudi. Bili smo na višse mjesta. Budi kod starijih ljudi pa im pomozi. Dok smo bili mladi spavali smo u podu u sijenu, ja i moja sestra. A nije to baš bilo lako i bode $i$ vruće, ali si im pomogo. Pomogli bi dorenut (donjeti) sjeno, pa ga smetnit (staviti) u pod, pogazit, jer nije bilo onih velikih štala i štaglja. Mizerno je bilo. A krave isto negdi smjesti, gdi bi bili smješteni kod tih ljudi.

57 Više o selidbi pčela na više nadmorske visine vidi u prilogu M. Rajković o pčelarstvu u nastavku ove monografije.

58 Detaljnije o tradicijskom graditeljstvu vidi u prilogu Ivane Šarić Žic u ovoj monografiji.

59 Milan Tomljanović Periša .

60 Milan Tomljanović Livak.

${ }^{61}$ Vidalica je otvor iznad ognjišta. Na krovu, veličine 80 - $30 \mathrm{~cm}$, imao je kanap (spagu) za koju si poteza ako si tia zatvorit ili otvorit. Neko je umjesto kanapa ima drvce, objasnio je isti kazivač. 
Ljetne stanove i kuće stanovnika na ovim prostorima možemo podijeliti u tri kategorije, kao što je vidljivo iz kazivanja Milana Tomljanovića Periše: ${ }^{62}$ U Zamaliću je bilo trinaest kuća, moja i još jedna su imale posebno štalu (sl. 1), a ostale dole blago, gore ljudi (sl. 2). A ti stanovi, isto tako dolje blago, gore ljudi. Bilo je slučajeva gdje su na ista vrata ulazili ljudi i stoka (sl. 3). A bilo je stanova s jednom prostorijom, sprezidom. Na jednoj strani spavali ljudi, na drugoj blago. Osim navedenoga na području Krivoga Puta postojali su objekti koje pod jednim krovom imaju dva ulaza, jedan za blago (u štalu), drugi za ljude (stambeni dio). Danas također pronalazimo takve objekte, no umjesto štale sada su tu ljetne kuhinje (sl. 4).

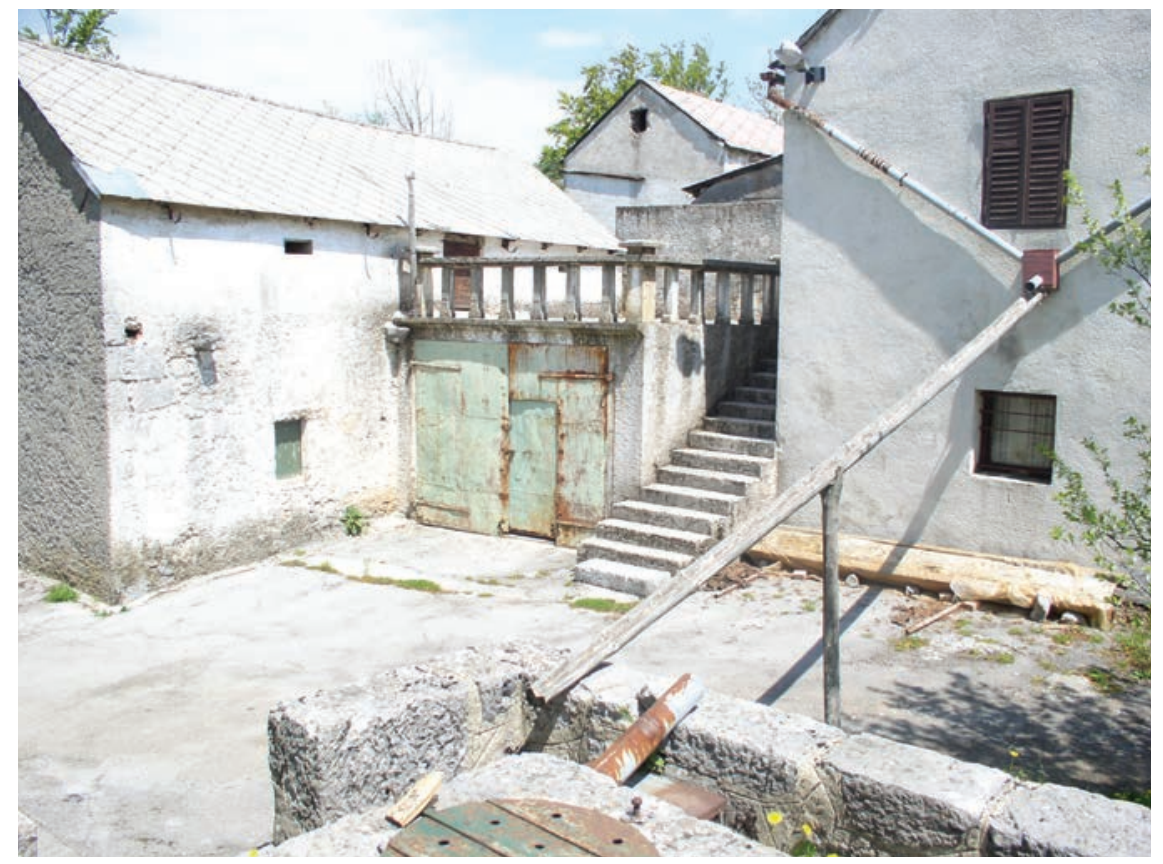

Slika 1: Stambeni kompleks, dio okućnice Milana Tomljanovića Periše u Zamalicu; snimila M. Rajković, svibanj 2004. godine.

\subsubsection{Ljetni stanovi u obliku pojate}

$\mathrm{N}$

ajjednostavniji oblik stana nazivali su pojatama. Pojate su bile od kamena, građene suhozidom, a sastojale su se od jedne prostorije pregrađene na dva dijela pomoću drvenih daščica ili kamena. U jednom dijelu boravili su ljudi, u drugom blago. Ulazile bi krave i ljudi na ista vrata, tu je bilo ognjiste $i$ visile su police sa sudem. Kad bi krava ulazila znala je bubnut i srušit sude (smijeh). ${ }^{63}$ Pojate su bile velike tolko da si moga uć glavom. Skošen, na koso krov od šimle, da ne curi na krave. Imala su niska vrata i mali prozorčić. Mogla su stat dva kreveta ili sečija sabita od dasaka (smijeh). ${ }^{64}$ Osim navedenoga inventara u pojati se nalazila drvena klupica i par stoličica, kaštrola (kotao) u kome se palenta kuvala, lonac i nekoliko padelica (manje zdjelice). ${ }^{65}$

Zabilježila sam samo jedan primjer ljetnog stana koji je imao oblik pojate, ali s dva ulaza. Znalo je bit pod jednim krovom sa dva ulaza, jedan za ljude drugi za blago. Kao da su dvi kuće, to je bilo u Kosovoj Buljimi, objasnili su bračni par Milan i Nada Prpić.

62 Kazivačeva je obitelj stalno živjela u Zamaliću, i bila je jedna od imućnijih.

63 Anka Šolić Tutanova.

64 Sečija se koristila umjesto kreveta. Zabiješ para dasaka na male nožice, pa metneš unutra malo slame u onu strožu ili kakve robe šta si imo, a nije bilo prije, kazala je Anka Šolić Tutanova.

65 Mirko Tomljanović Sova, Petar Tomljanović Čona, Tome Špalj Cucin, Petar Tomljanović Jukša. 


\subsubsection{Ljetni stanovi na kat}

Drema svim kazivačima na cijelom području Krivoga Puta najrašireniji oblik kako kuća tako ljetnih Ltanova bile su nastambe u kojima su u prizemlju boravile životinje, a na katu ljudi (sl. 2). Donji, prizemni dio nazivao se štalom, a gornji dio kuća. Nastamba je bila od kamena, donji dio bio je dijelom ukopan u zemlju da bi životinjama bilo toplije, posebice zimi. Zbog nedostatka pijeska strop je najčešće bio od drvenih dasaka. Unatoč tome što se kroz daske širio neugodan miris od životinja, mojim kazivačima, tadašnjoj djeci one su ostale najviše u sjećanju. Meni ko ditetu bilo bi interesantno odozgo kroz daske gledat krave, uzmi bateriju pa im svitli kroz daske. ${ }^{66}$ Pogotovo kad bi bilo malo tele, gledaj što radi, prisjetio se Milan Tomljanović Livak jednog od razloga zašto je volio boraviti kod bake i djeda na ljetnom stanu.

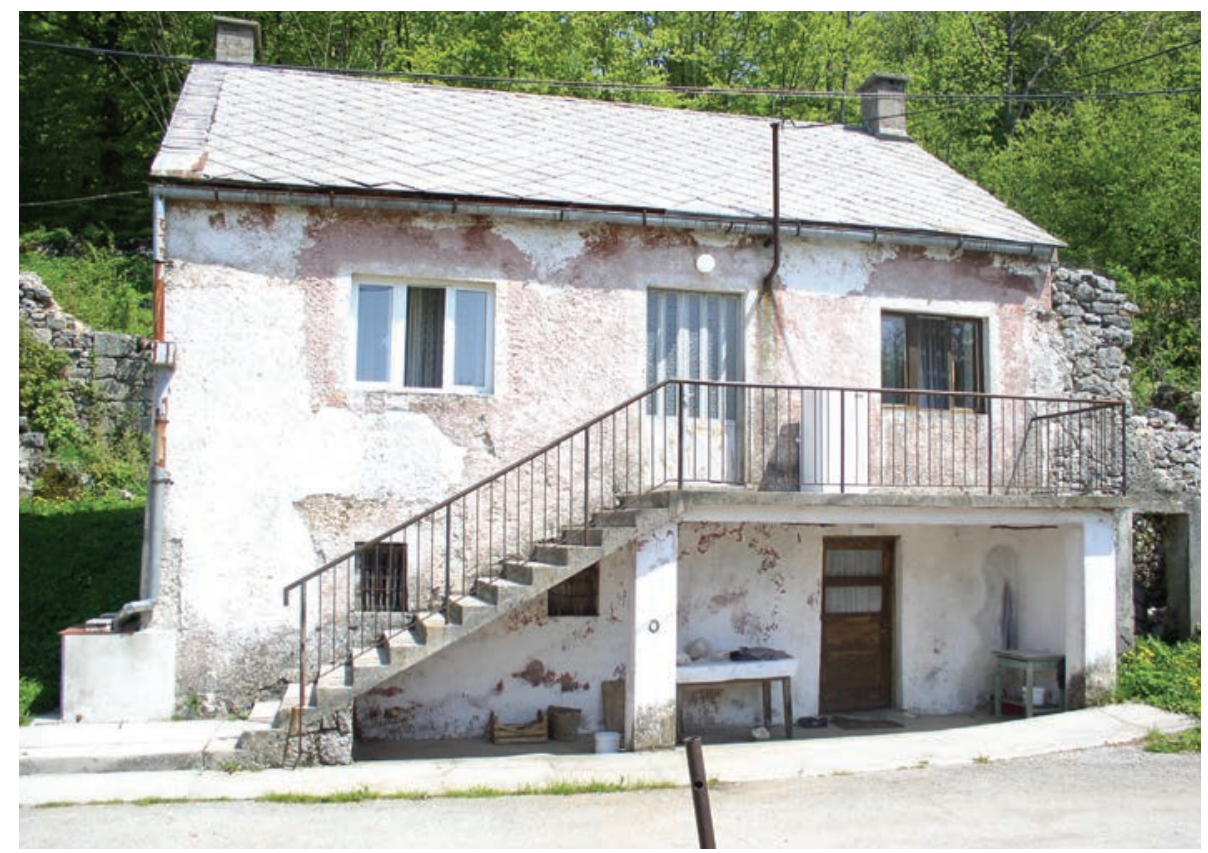

Slika 2: Kuía Mladena Butkovića Gare na kat iqgradena 1765. godine (kasnije nekoliko puta adaptirana), Alan, vlasnik obitelj Butković Garini;; snimila M. Rajković, svibanj 2005.

Gornji dio, zvan kuća bijelio se vapnom do pola. Od inventara bilo je otvoreno ognjište ${ }^{67}$ i komoštre, kasnije limeni šparhet koza (peć). S ognjišta je bila velika ‘ko škulja (otvor), a u sobi je bila pećsa petnjaci. To si moga tamo se grijat, a odavde si moga mećat drva i ciplje, sta si tia ${ }^{68}$. Pokraj ognjišta su bile tronoge, na tom se kuhalo jelo u padeli ili mliko, a u kastroli se kuhala palenta, krumpir i vako jela. Kruh, meso i krumpir pekli su pod pekama. U istoj prostoriji bio je mali ili veliki stol. Oko malog ljudi sjedili su na tronošcima, a oko velikog (koji su se počeli upotrebljavati iza Drugoga svjetskog rata) na stolcima. Stol je bia sabit od tri daske na četri noge, ili je bia okrugli malo manji na tri noge, polica za sude pričvršćena na zid. ${ }^{69}$ Kreveti zvani peršona i po (širi od današnjih tako da je dvoje odraslih ili četvero djece moglo spavati na njemu,) rađeni su od punog drveta te su bili razdvojeni svaki za sebe. Umjesto madraca upotrebljavale su se slamarice

66 Razmak između dasaka bio je otprilike jedan centimetar i smrdilo je odozdo, isticali su mnogi kazivači. Poneki su upotrebljavali šipeline daske tako da nije mogo neukus dolazit odozgo. Jedna u drugo uđe daska to se zove šipel, kazali su Milan Prpić Brkac i Nada Prpić Grgaica. Imućnije obitelji su radile plafon od pijeska i vapna, kazala je Anka Butković Matićeva.

67 Ognjišta su se počela zamjenjivati pećima tzv. kozama, a za vrijeme Drugoga svjetskog rata na ognjištima su kuhali za svinje. U pojedinim obiteljima takve se prostorije danas koriste za dimljenje i sušenje mesa.

68 Anka Šolić Tutanova.

69 Od posuđa koristilo se: velike zdile za donjit na stol svoj familiji, cinjani pinjati (aluminijski tanjuri), paljak (kutlača za grabit juhu). 
od ječma, ${ }^{70}$ pšenice, a ko je bolje stajao taj je imao slamaricu od kukuruza, ali to je bio luksuz. ${ }^{71} \mathrm{Na}$ slamaricu se stavljao štramac od vune. Imućniji su koristili samo vunene štramce (oko desetak centimetara debljine $)^{72}$. Umjesto dekama, pokrivalo se ličkim vunenim biljcima. ${ }^{73}$ Spavalo se $i$ u podu gdje je seno bilo. Bilo je toplo, moga si spavat bilo gdje. ${ }^{74}$ Tekstilne predmete držali su u škrinjama, u borovima s tri ladice ${ }^{75}$ ili u ormarima.

Budući da je struja uvedena tek sedamdesetih godina 20. stoljeća za rasvjetu su korištene svijeće i petrolejke. Neimaštine koju su kazivači stalno isticali, Tome Špalj Cucin prisjetio se kroz riječi koje su stari stalno ponavljali: Nemoj još palit, rano je. Idemo spavat. Nemoj trošit sviću. A nije bilo ni petroleje.

Svi su Krivopućani naglašavali da blago nikada nije ostajalo noću vani u toru zbog opasnosti od vukova. Pojedini stalni stanovnici, kada su im to dopuštale imovinske prilike, pored ovakvih nastambi napravili su štale u kojima su boravile životinje, kao primjerice na području Alana u obitelji Milana Tomljanovića Periše: Ja sam imao

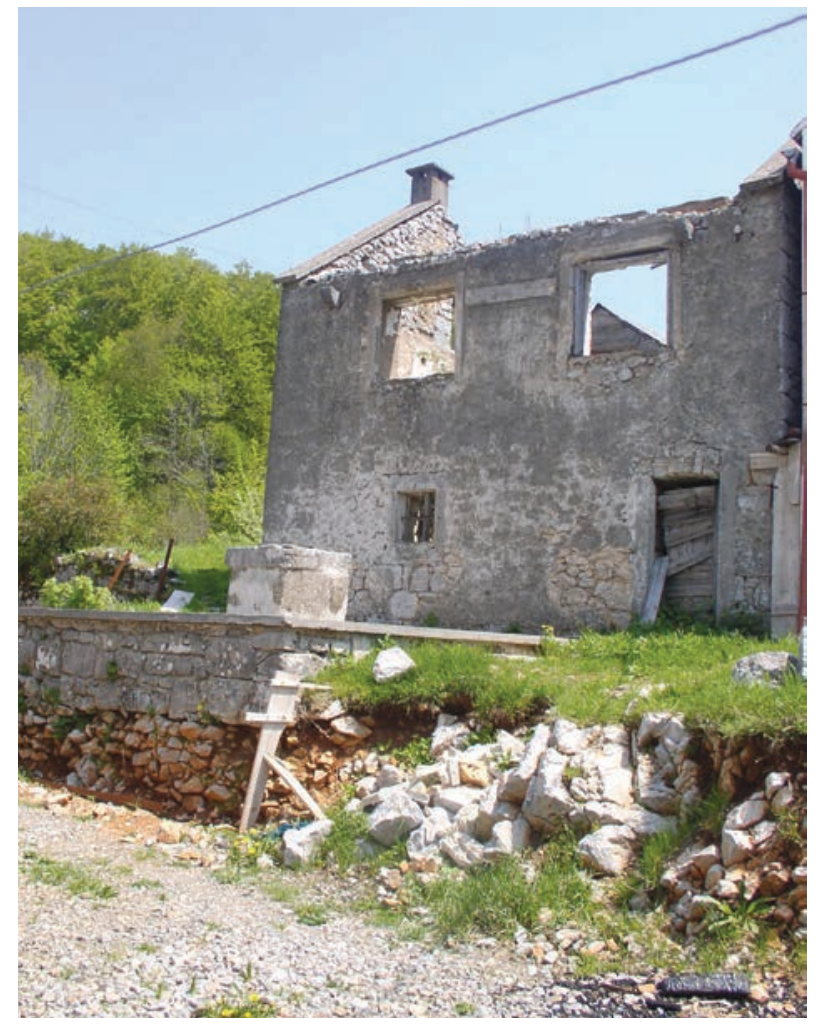

Slika 3: Kuía s jednim ularom, Alan; snimila M. Rajkovic; svibanj 2005.

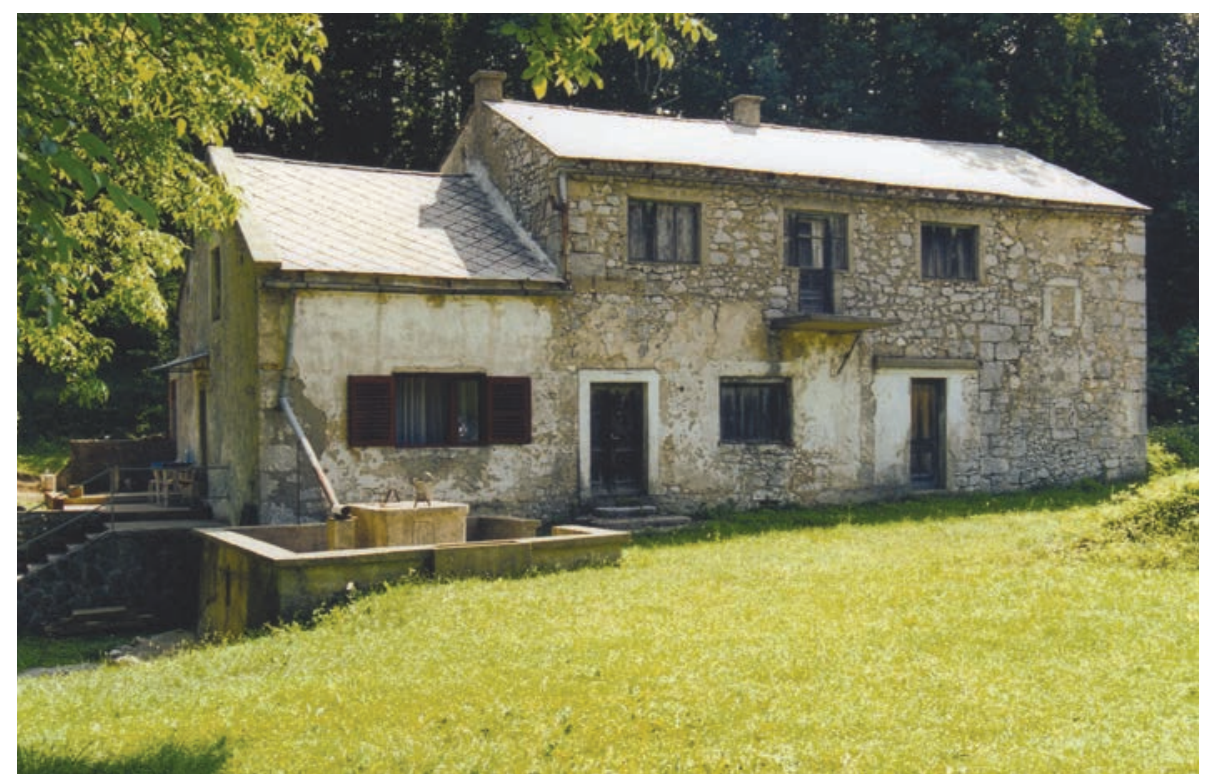

Slikea 4: Kuía s dva ulaza (kasnije napravlien i treći), Mrzli Dol; snimila M. Rajković, svibanj 2005.

70 Bilo je poželjno da se ječmena slama svake godine promijeni, no tko nije imao promijenio bi svakih nekoliko godina.

71 Mira Ostović Šare.

72 Štramci su se uglavnom nabavljali u Lici, a dobar štramac morao je težiti barem šesnaest kilograma vune.

73 Detaljnije o tekstilnom rukotvorstvu vidi više u prilogu A. Vlatković u drugom svesku Monografije.

74 Petar Tomljanović Jukša.

75 Boro se koristio za spremanje tekstilnih predmeta. Bio je niži od ormara, s tri ili četiri ladice koje su se izvlačile kao kutije, objasnila je Anka Šolić Tutanova. 
posebno štalu posebno kuću. Moj djed i otac otkad pamte se bavili s kirijom. Imali su konje, obično po dva, a onda su malo bolje živjeli. Ostali su imali tako da su ljudi stali gore, blago dolje. Kada u donjem dijelu nije bilo smješteno blago taj je prostor imao drugu namjenu što se vidi iz kazivanja bračnoga para Nade i Milana Prpića: Ako nije bilo doli blago onda smo to zvali konoba za smještaj hrane, nešto što bi trebalo za ljude i blago, korabe, krumpir.

Razlike između nastambi domicilnoga i migratornoga stanovništva ovisile su o imovinskim prilikama, pa tako i interijer istih. Razlika je što su Primorci sa sobom nosili sav sitni inventar i tekstilne predmete.

\subsection{ODNOSI IZMEĐU MIGRATORNOGA I DOMICILNOGA STANOVNIŠTVA}

$\mathrm{P}$ osebice me zanimao društveni život, odnosno granice društvenih zajednica, u ovom slučaju domiciloga i migratornoga stanovništva. To sam nastojala saznati pomoću određivanja komunikacijskoga lanca koji se uspostavljao ženidbama i kumstvima između Primoraca i stalno naseljenih Krivopućana. ${ }^{76}$

Ženidbene veze na području Krivoga Puta uglavnom su bile endogamne. ${ }^{77}$ Odnosno, mladi iz primorskih sela sklapali su brakove međusobno, a mladi iz krivoputskih sela na većim nadmorskim visinama između sebe i to ponajviše unutar svoga sela. Ženili smo se izmedu sebe, a bilo je rijetko da su se cure iz Primorja udavale ovdje ili ovdašnje za Primorce, budi rodena $i$ udata Vukelić. ${ }^{78}$ Kazivači su navodili da su brakove sklapali Primorci i Krivopućani s viših nadmorskih visina, no kad sam ih zamolila da navedu primjere navodili su tek pojedinačne slučajeve. Tako je jedna djevojka iz Sibinja bila udana u Podbilo početkom 20. stoljeća te nekoliko djevojaka sredinom 20. stoljeća. Jedini kazivač koji je trajno stanovao na višim predjelima te oženio djevojku iz Primorja, bio je Milan Tomljanović Periša iz Alana: Iz Sibinja je jedno sedam, osam familija selilo na Alan i upoznali smo se dokje ona bila gore. U jesen su oni salazili i onda sam ja iz Alana išo preko Butković Dolca, Šušnja, Vodne Drage na Sibinj pješice ofirat š njom. Onda smo se poslije oženili.

Nisam zabilježila slučaj da se neka djevojka iz Primorja udala u Alan, no bilo ih je iz Francikovca i Krivoga Puta. Isti je kazivač naveo da se puno djevojaka iz Sibinja udalo u Novi Vinodolski i Senj. Kazivači se ne sjećaju da je momak iz stalnih naselja oženio Primorku i otišao živjeti u Primorje te selio na ljetne stanove. Početkom druge polovice 20. stoljeća djevojke iz Krivoga Puta češće su se udavale za Primorce, ali one više nisu selile, već bi se bračni par nakon vjenčanja preselio u Senj.

Svi kazivači navodili su da su se između Primoraca i stalno naseljenog stanovništva sklapala prijateljstva i kumovske veze. No tek su se rijetki prisjetili konkretnoga primjera, tako je primjerice Petar Tomljanović Čona iz Podbila naveo: Ja sam bio pet, šest puta kum Primorcima, vjenčani i krsni. Glavna osobina po kojoj se odabiralo kuma bilo je prijateljstvo između ljudi. Gledalo se da su si ljudi dobri, nije to bilo bogatih, ja ne znam da mi je kum šta poklonio, kazala je Anka Šolić Tutanova.

\subsection{GOSPODARSKA ORGANIZACIJA ŽIVOTA}

$\mathrm{U}$

Tovom prilogu namjera mi je prikazati samo razinu svakodnevne interakcije između dviju skupina stanovništva prilikom obavljanja poslova vezanih za zemljoradnju te organizaciju ispaše blaga. Primarni cilj ovoga rada nije bio istražiti simbolične granice između dviju zajednica, odnosno strategije autoidentifikacije kojima se migratorno i domicilno stanovništvo razgraničuje jedno od drugog, no kada se dvije zajednice paralelno istražuju takav pristup se sam po sebi nameće.

76 Usporedi s radom J. Čapo, 1988:13.

77 Više o svadbenim običajima bit će objavljeno u drugom svesku Monografije.

78 Anka Butković Matićeva. 


\subsubsection{Zemljoradnja ${ }^{79}$}

Od povrća sadili samo krumpir, salatu i peršin, a da su mrkvu, zelje, korabu to ništa. Ovi koji su tu bili stalno možda, al' malo se toga sadilo. Danas ja više sijem nego prije deset kuća, sijem i paradajz $i$ papriku, a prije smo kupovali zelje. Obradivali smo svako svoju zemlju, nije bilo ko bi kome da. Sijali smo ječam, a jedno dva put šenicu, kad sam bila u Krvom Putu onda sam i heljdu za prasce sijala, $u$ Podbilu nisu ni znali što je to. Oni su sijali zob, to smo i mi sijali, al' ne svake godine, jer nemaš di, objasnila je Anka Šolić Tutanova.

Jedan od razloga zašto su Primorci obrađivali manje zemlje od domicilnog stanovništva bio je taj što su zemlju obrađivali ponajviše motikama. Nismo mi imali ništa samo motiku i đubar stavi. ${ }^{80}$ Kazivači ističu da nitko iz Primorja nije imao ralo ili plug, pa čak i kada su imali konje. U slučajevima kada su imali veće površine zemlje posuđivali su sprave za obradu zemlje od domicilnog stanovništva. ${ }^{81}$ Ako bi orali na posudene konje ili volove, e zavisi ako gazda ima vremena i ako je ovaj star i nemoćan onda odi gazda sam, ako je ovaj mlad i dobar gospodar, onda mu daj da sam izore. Nije se plaćalo već se vraćalo. Odi radi, dođi gazdi kosit, kopat. Ti danas ja ću sutra, nije prije bilo novca. A neko i plati, neko ti je prijatelj, kako ko se dogovori. Za tu zamjenu bi se kazalo. Idem pomagat kumu ili komsiji, kazao je Ivan Krmpotić Bokula.

Najčešći oblik naknade vidljiv je iz kazivanje Marka Pavelića Mijatine: Ti Primorcu, što treba napravi, posij zemlju, kosi, a on tebi zidaj kuću ili šternu, žbukaj kuću, štalu pokrivaj. Primorci su bili najbolji zidari, ako si ga zva doša je. A uzajamno se radilo. Simbolično razgraničavanje na "mi" i "oni” vidljivo je i kroz osobne identitete pojedinih pripadnika, odnosno njihovim zanatima. Nama je Joja iz Primorja zidao zidane peći, to smo imali svi na Alanu, on je bia dobar majstor. ${ }^{82}$ Primorci su bili dobri zidari, imali su svakakvog zanata, a mi nismo imali zanate, jedino ako neko budi samouk. ${ }^{83}$

Osim navedenoga Primorci su od domicilnog stanovništva ponekad posuđivali i sitni inventar, primjerice grablje, konop, burilo za vodu. Mi smo svi bili dobri, nije bilo razlike ko gdje živi, oni nama smokava donesi i murva (duda), a mi njima daj drinula (plodovi drena), kruske, jabuke, jer to nije uspijevalo u Primorju, kazao je Petar Tomljanović Čona.

\subsubsection{Organizacija ispaše blaga ${ }^{84}$}

Z imi je blago bilo u štalama, kako u planinama tako i u Primorju. U ostala godišnja doba zbog nedovoljne količine sijena i hrane, kada je god to bilo moguće, dakle kada nije bilo snijega, blago je išlo na ispašu. U ovom odlomku namjera mi je bila pokazati organizaciju čuvanja blaga u vrijeme kada je na planinama boravilo i migratorno stanovništvo. Kazivači su isticali nedostatak obradivih površina te nepostojanje privatnih pašnjaka, stoga je blago najviše paslo na državnom zemljištu. Razlike su ovisile o godišnjim dobima, kazao je Tome Špalj Cucin: U proljeće je blago širom paslo, al'pazilo se da se ne ide na oranice i livade, a kad se pokosilo moga si ić bilo gdje, širom. Posebice u jesen kad bi se pobrala ljetina. Blago bi išlo na pašu i po tri kilometra. Primjerice iz Podbila u Vratarušu, Šušanj. Životinje su imale stazu kojom

79 Više o zemljoradnji vidi u prilogu M. Rajković u nastavku ove monografije.

80 Anka Šolić Tutanova.

81 Milan Tomljanović Livak kazao je: Plug i jaram je obično ima jedan čovik u selu ili dva. Onda su se time služili svi. Ako bi bia jedan konj $i$ to je bia drveni plug. Posudivali bi ili bi taj gazda od konja i pluga iša danas ovom orat a taj bi njemu za uzvrat radio. Ovom u prilog ide i kazivanje Anke Šolić Tutanove: Moj muž je prvi kupia željezni plug i kolica (pedesetih godina 20. stoljeća op.a.). Drugi su imali drvene plugove. To su poslije bila i kolica željezna i drlja. A muž je poslije napravio drvenu pa se okovala željezom, bila je dobra, teška. Zemlju smo ravnali mlatačima (predmet izrađen od drveta, dugačak oko $40 \mathrm{~cm}$ širok $10 \mathrm{~cm}$, drži se pomoću duge drške).

82 Anka Butković Matićeva.

83 Milan Tomljanović Livak.

84 Više o stočarstvu i organizaciji ispaše vidi u prilogu M. Rajković u nastavku ove monografije. 
bi išle, tako da ne rade kvarove (ulaze u ljetinu), moralo se pazit na njih. Velika opasnost u ovim krajevima su vukovi zbog kojih su stanovnici izbjegavali držati velik broj ovaca. Uz blago je uvijek morala biti jedna osoba, odnosno čoban.

U daljnjem tekstu prikazat ću primjere organizacije čuvanja blaga prema pojedinim lokalitetima.

U Podbilu nije bilo određeno di će se blago vodit na pašu, to vodi di oćešs. Al' bilo je vražjih ljudi koji nisu dali na svoju zemlju. Gonili smo najviše niz planinu to je bilo državno. Nije da smo mi imali livade za pašu, to se sve kosilo. Kada sam ko cura selila iz Primorja, sami smo svoje gonili. A Žuljevići su se jedno vrime s nama redali, jer je to isti put. Stričevi i tete koji su selili iz Primorja isto goni svako svoje. A Podbilari bilo puno blaga, konji, krave, ovce nismo se medusobno redali. Blago iz Podbila nije išlo zajedno na pašu, idi posebno Cupići, ${ }^{85}$ posebno Tomići i posebno Panjići oni su bili najveći, gusto naseljeni, ako su išli i konji onda su išla dva čobana. A malo kad se to mišalo, bili bi čobani zajedno al' rasporedi blago svako na svoju stranu jer bi se ovce smišale pa onda ne znaš čije su. Ovce su ljudi malo držali, ako je kuća imala s janjcim najviše do petnaest, jer nisu ih zimi imali 'di držat, ni š̀im hranit. Onda smo se redali i blago vodi na pašu. Recimo vako, danas je moj red, a tu okolo su bile tetke i polutetke njih četiri. I svi oni danas moraju meni ispratit blago isprid kuće onda ja gonim prema Vratarusi. ${ }^{86}$

U Krivom Putu bilo je pet kuća od ljudi koji su tu ljeti boravili. Oni su imali puno djece. Imali su koze, a one su nemirne ko davo, pa je iz svake kuće išlo jedno dijete, baš ovi moji vršnjaci oni su išli svaki dan. A nas pet kuća smo se kladali (redali), svaki dan drugi, al smo išli svi zajedno. ${ }^{87}$

Iz Šušnja, Kosove Buljime, Vrataruše i Butković Dolca blago je za svako mjesto išlo posebno na pašu. Iz svake kuće išla je jedna osoba kada je na nju došao red. No svi su se čobani sastali na istom pašnjaku.

$\mathrm{Na}$ Alanu je bilo desetak kuća stalno naseljenih i svaki deseti dan je bio vaš red. Bile su 32 krave, magarci i konji. A ovi teški konji za kiriju nisu išli na pašu, njih su doma hranili. Ovaca je bilo jako malo. Nije niko imo ovce osim mene, imala sam petnaest komada. A prije toga žene iz Alana nisu nigdi prodavale mliko već su ga davale svinjama, ${ }^{88}$ kazala je Anka Butković Matićeva. Primorci su svoje posebno čuvali, nisu se miješali s nama, ali je išlo na isti pašnjak. Oni su imali puno krava, jer su mlijeko nosili prodavat u Senj. ${ }^{89}$

Prema podacima za pojedine lokalitete može se primijetiti da je ispaša ovisila o količini i vrsti životinja (veći broj krava, koze), te o broju stanovnika pojedinog sela i zaselka, no uglavnom su svi napasali blago na istim državnim pašnjacima. Ako znamo da je primjerice u Šušnju, Kosovoj Buljimi, Vrataruši i Butković Dolcu živjelo domicilno i migratorno stanovništvo, možemo zaključiti da je skrb oko životinja tijekom ispaše bila zajednički organizirana. Na ostalim područjima Krivoga Puta (primjerice Mrzli Dol, Veljun) prema riječima kazivača živjeli su samo stalni stanovnici.

85 Vukelić Ivan Mikula kazao je: Isla su dva čobana redalo se u dva reda, nas je petero u redu vamo četvero ili petero pa se redaj svaki dan iz jedne kuće. Upet dana iđeš jednom.

86 Anka Šolić Tutanova.

87 Tome Špalj Cucin.

88 U drugoj polovici 20. stoljeća svaka je kuća imala od dvije do četiri krave iz razloga što se u Alanu organizirao otkup mlijeka do 1970-ih.

89 Ivanka Atalić Garina. 


\section{SILASCI U PRIMORJE}

\subsection{DNEVNI SILASCI}

D azlika u tradicijskom gospodarstvu između migratornoga i domicilnoga stanovništva bila je i u tome Ršto su Primorke nosile prodavati mlijeko u Senj neovisno o tome jesu li živjele ljeti u planini ili zimi u Primorju. ${ }^{90}$ Tako su primjerice u Senj nosile mlijeko iz Vrataruše, Bunice pa i najudaljenijeg Alana, za razliku od Alanarki koje su imale krave samo za svoje potrebe ili su višak mlijeka davale svinjama. Život mljekarice ocrtao je Milan Tomljanović Livak: Baba se digni u 4, dok bi pomuzla krave bilo je već 5, da bi u Senju bila oko 7 sati. Od Vrataruše do Senja ima negdi oko 8-9 kilometara, dva, dva i po sata hoda. Na magarca stavi dvi late u svakoj bi bilo 5 litara mlika i to goni u Senj svaki drugi dan. Ona je bila stara i nije mogla na magarcu jašit. Baba stara, a magarac nejak. Tamo su imale svoje konte, žene kojima su prodavale to mliko. Neko bi joj plača u novcu, a neko je dava u zamenu cukar, brašno, tijesto. Uglavnom je to sve bilo jadno, sirotinja sve.

Suprotno tome poneki su smatrali da su Primorci imućniji od domicilnih stanovnika što se vidi iz sljedeće naracije: Oni su prodavali mliko u Senju, po zimi a neki su i liti nosili, imali su one jake mule, oni su dobro živili. Za mliko bi kupili u Senju što im treba, a bio im je blizu i grad. ${ }^{11}$

Primorci su često silazili u svoja zimska naselja neovisno o prodaji mlijeka. Na mulama i magarcima kasno navečer ili u ranu zoru po kozjem putiću silazili su prema potrebi i gonili sjeno, drva, krumpir i žitarice. Dakle, dolje su silazili pješice, a uspon na planinu ovisio je o tome nose li stvari. Onda ako je mula bila prazna uzjaši, a ako nije, moraš pješice. ${ }^{92}$ Stoga je i nastala šala: Teško muli ili konju koga dadu dole u Primorje! Taj nikad nema mira, stalno seli. ${ }^{33}$ Razlog silaska bila je i prilika da se susretnu s članovima obitelji koji nisu selili. A ne bi svi odozdo ni selili. Teta bi ostala doli nije selila, pa bi nas dočekala kada bi mi gonile drva i seno za zimu za blago, kazala je Anka Šolić Tutanova.

\subsection{JESENSKI POVRATAK}

U kasno ljeto, iza Velike Gospe (15. kolovoza) ${ }^{94}$ silasci u Primorje bili su gotovo svakodnevni. Intenzivno su prenašali sijeno i drva. Stalni silasci na zimska naselja ovisili su o odluci unutar obitelji, a započinjali su češćim silascima, odnosno prenašanjima ljetine u trajna zimska naselja. Selili su tijekom rujna nakon što su pokopali krumpir, ${ }^{95}$ krajem rujna, prid Miholju (29. rujna spomen-dan je sv. Mihaelu), ${ }^{96}$ početkom listopada, kad budi ledeno i počne padat u jesen do studenoga dok ne počnu zime. ${ }^{97}$

Svim kazivačima najzanimljivije su bile jesenske selidbe velikih svinja. Naime u proljeće su kupili male svinje i hranili ih kroz ljeto za kolinje u jesen. Svinje (smijeh) kupi u proliće miće (male) $i$ izrene gore, a u jesen je on veliki. E, onda triba pravit od drveta sane is njim unutra $i$ vozi ga. To se napravi ko kutija, odozgora zatvoreno. ${ }^{98}$ Ja sam umra od smija kad sam to prvi put vidia, kazao je Milan Tomljanović Livak: Did je napravia velike saonice negdi dva metra dužine i metar širine i unutra bi stavio prase i to bi zabio daskama da

\footnotetext{
Više o mljekaricama vidi u prilogu T. Rubić u ovoj monografiji.

1 Anka Butković Matićeva.

92 Anka Šolić Tutanova.

93 Tome Špalj Cucin.

94 Milan Tomljanović Livak.

95 Anka Šolić Tutanova, Tome Špalj Cucin, Mladen Šojat Bilin.

96 Anka Butković Matićeva, Milan Prpić Brkac.

97 Milan Tomljanović Periša.

98 Milan Prpić Brkac.
} 
ono ne može van. To bi mula vukla iza sebe na onaj konop (uže). Onda to se uvik pazilo, nosili smo dvi poluge ako negdi zapne za kamen da se može pomaknut.

No zabilježila sam i dogodovštinu koju je gledao Milan Prpić Brkac kada je svinja umalo izbjegla kolinje: Ja se sećam primera kada je jedan selia svinje pa mu mula nije mogla gore uz brdašce pa mu doša prijatelj iz Kosove Buljime i posudia konja. Prasac napravio vum (groknuo op.a.) konj se poplašia, razbio kutiju $i$ svinja se istresla (smijeh) i ode ća. E, onda su ju lovili po planini (smijeh).

\section{OSTALE SPECIFIČNOSTI}

$\check{S}^{\prime}$ to zbog načina života na dvije lokacije, a što zbog odluka nadležnih upravnih tijela gdje će sagraditi osnovne škole i crkvu, na ovom mikro ekosustavu Krivoga Puta život se kroz čitavu godinu odvijao isprepleten svakodnevnim migracijskim mobilnostima, pa tako i za potrebe osnovnoškolskog obrazovanja i vjerskih praksi.

\section{1. ŠKOLOVANJE}

$\mathrm{U}$ ovom odlomku cilj je ukazati na udaljenosti škola u koje su išla djeca iz primorskih naselja. ${ }^{99}$ Prva osnovna škola na ovom području otvorena je u Krivome Putu 1846. godine (Raguž, 1999:344) i nju su pohađala djeca sa šireg područja. Nakon toga napravljene su ostale škole, primjerice u Alanu. Kad sam ja išo bila je škola na Alanu, 1927./ 8., 1930-te, i moj pokojni ćaća je išo u tu školu. Tu se išlo četri razreda. Svi smo išli zajedno, blo nas je pedeset daka. Onda su poslije napravili razrede, kazao je Milan Tomljanović Periša. "Tijekom 19. i 20. stoljeća na području Krivoga Puta, koje obuhvaća naselja: Alan, Vratarušu, Podbilo, Klaričevac, Krivi Put, Mrzli Dol, Veljun i Francikovac djelovalo je šest pučkih škola: Krivi Put, Alan, Vrataruša, Podbilo, Mrzli Dol i Veljun.” (Usp. Raguž 1999:343). Dakle, primjećujemo da je najbliža škola primorskoj djeci bila u Vrataruši, naime sve ostale su na višim nadmorskim visinama. "Osnovna škola u Vrataruši otvorena je godine 1937, a zatvorena godine 1963.” ${ }^{100}$ Nastava je počela nešto prije nego što su mještani izgradili školu u privatnoj kući. Kada su "mještani izgradili svoju školu u Vrataruši je bilo 13 kuća.” (Ibid. 353). Neovisno gdje su stanovali, Primorci su i ljeti i zimi išli u tu školu. Djeca iz svih Primorskih sela išla su u osnovnu školu u Vratarušu. Sjećanja o pohađanju škole, saznajemo iz naracija Anke Šolić Tutanove: Iz Sovine Drage u školu smo išli na Vratarušu, al to je bilo daleko. Ja nisam išla nego godinu $i$ po. Mi smo išli pješice po sat i više. Bilo daleko ko bi iša. Onda smo posle išli u Sibinj u školu ko je tia. Ja nisam išla. Moja sestra išla do kraja četvrtog razreda. I ostala djeca su iz Sibinja išla u Vratarušu, al malo ih je došlo do kraja jer bila zima i ledeno, pa ko bi iša. Kada je bio velik snijeg bilo je opravdano. Milan Tomljanović Periša kazao je: Zimi kad bi bilo jako zima znali bi prenoćit kod neke rodbine. A teško je to bilo. ${ }^{101}$

Kazivači smatraju da je to ujedno bio razlog što djeca nisu nastavljala školovanje. Do četvrtog razreda idi, a nakon toga: Mili moji kuda koji! Bilo je djeci teško ić pješke u školu, al ajde. ${ }^{102}$

Područne škole zatvarane su 60-ih godina 20. stoljeća, nakon čega su djeca mogla ići u školu jedino u Krivi Put jer ta je škola najduže djelovala.

Od šezdesetih godina 20. stoljeća selidbe na ljetne stanove postale su sve rjeđa pojava. Paralelno su se u punom zamahu odvijali procesi prelaska stanovništva iz poljoprivrednih u nepoljoprivredne djelatnosti. Deruralizaciju ovih prostora započelo je školovanja mladih u bližim urbanim središtima te nakon toga zapošljavanje. Jel to je bilo daj djetetu zanat, kako bilo. Onda su djeca ostajala živjet u gradu, i ostala gore star-

99 Više o školstvu vidi u prilogu Blaženke Ljubović u ovoj monografiji.

100 Nakon što je škola zatvorena, djeca su usmjerena u školu u Krivome Putu (usp. Raguž 1999:355).

101 Od Sibinja do Vrataruše je bilo sat i po hoda po pješačkoj stazi.

102 Milan Tomljanović Livak. 
čad. ${ }^{103}$ Mi smo rano otišli odatle, imao sam četrnaest godina. Nas 32 je završilo 8. razred u Senju, i svi smo otišli u zanatiće. Čak jedan, bili su jako siromašni i nisu ga mogli školovat pa je oša za popa jer se tako mogo besplatno školovat. Al je posle ošo u vojsku i nije osto pop. Sad ima obrt, kazao je Milan Tomljanović Livak. Nakon odlaska djece stanovnici koji su stalno živjeli na oko 500 do 600 metara nadmorske visine nastavili su ondje živjeti, odnosno poneki seliti na te iste ljetne stanove iz Primorja još kratko vrijeme. Prodaj krave, ovce pa kad višse nisu mogli, pogotovo kad bi jedno umrlo, došli djeci u grad. Moja mama je iz Šušnja otišla predzadnja došla je u Senj 1968. godine. A zadnji su se iselili 1969. godine, kazao je Zlatko Tomjanović Kaić.

\subsection{VJERSKI ŽIVOT ${ }^{104}$}

7 a područje Krivoga Puta župna crkva nalazi se u Podbilu, a posvećena je Majci Božjoj Snježnoj. "Cijeli kraj Krivoga Puta spadao je pod župu sv. Jakova u Krmpotama. Oko 1794. osnovana je župa Krivi Put sa središtem oko crkve Marije Snježne.” (Raguž 1999:344). Dakle, stanovnici iz Primorja odlazili su na bogoslužja u crkvu u Podbilu, neovisno o tome jesu li stanovali u Primorju zimi ili na višim nadmorskim visinama ljeti. Anka Šolić Tutanova svoje odlaske na misu ocrtala je: Kad smo bile cure onda smo išle gore svake nedilje u crkvu. Pješice, izuješ se, ideš bos da ne podereš cipele ili što navučešs, pa se obuješ kad dođeš pred crkvu. Djeca rođena u Primorju nosila su se krstiti u Podbilo ili u Senj. Razlog tome navodi ista kazivačica: Nama je jednako do Senj i dovde šest kilometara, a nije bilo prije autobusa, jedino je brod iša. $A$ auta nisi vidio možda jedan u godini.

\subsection{SAHRANE}

$K_{d}^{2}$ ada je netko na ovom području umro, sahranjivali su ga također u Podbilu, dakle i iz primorskih područja, točnije Šušnja, Kosove Buljime, Bunice, Sv. Jelene, Sovine Drage, Vodne Drage, Francikovca, Veljuna. Iz Sibinja su nosili mrtvaca u Podbilo do 1945. godine, a nakon toga su napravili u Sibinju crkvu i groblje. Razlog zašto se danas većina Krivopućana koji žive u Senju pokapa na istom groblju objasnio je Zlatko Tomjanović Kaić: Kod nas je rano gore napravljena crkva i formiralo se gore groblje. Mi smo svi gravitirali gore, jer gore nam je bila zadruga i sve. Da ja umrem kopali bi me gore, jer nam je gore grobnica. Da ne zapuste roditeljske grobove ljudi su napravili grobnice. A što će radit nove u Senju.

Dakako, pokojnika je s područja nižih nadmorskih visina trebalo donijeti do Podbila. Stoga su četiri muškarca nosila pokojnika na nosilima posebno izrađenim za tu priliku, ${ }^{105}$ to je bila muka nosit na ramenima. Povorka ${ }^{106}$ je išla kozjim stazicama, a kako je groblje bilo udaljeno i po šest sati hoda, muškarci su se izmjenjivali. Prije je bilo puno ljudi, onda se mijenjaj u hodu, jedan pusti drugi primi, ali lijes se nije spuštao. Mjesto gdje bi se lijes spustio je bilo strogo odredeno, zvalo se počivalo, mi tamo malo počivaj. Tamo smo znali lijes spustit na zemlju pa odmori malo, jedno pol sata, kazao je Milan Tomljanović Periša. ${ }^{107}$ Lijes bi spustili pokraj puta. Znalo se gdje je počivalo. Di je koji kamen, drvo, raskršće ili malo proširen put. ${ }^{108}$ Svi

${ }_{103}$ Zlatko Tomjanović Kaić.

104 Više o ovoj temi vidi u prilogu biskupa Mile Bogovića u ovoj monografiji.

${ }^{105}$ Milan Tomljanović Periša opisao je nosila: To su bila dva dugačka kolca, morali su bit duži od lijesa, recimo ako je lijes dva metra kolci su morali bit tri metra. Sanduk svežu konopom na te vrlike i četiri lengera (letve).

106 Povorka je bila formirana: predvodila ju je osoba koja nosi križ, pa lijes, zatim uža rodbina (muškarci i žene zajedno), prije su hodali svi zajedno (nije zabilježeno vrijeme kada). Danas muškarci idu prvi, a zatim žene. Kazivači nisu znali objasniti razlog, osim Milana Tomljanovića Periše koji to smatra iskazivanjem veće časti muškarcima.

107 Primjerice od Alana do Podbila bilo je jedno počivalo kod zaseoka Cupići. Od Šušnja do Podbila bila su dva počivališta.

108 Za detaljniji uvid o počivalima upućujem na rad etnologa M. Gavazzija (1987), a o mirilima na Velebitu na radove Mire Trošlje: Ukrasi i simboli na južnovelebitskim mirilima na području Starigrada-Paklenice, Senjski zbornik 9, 19811982, 115-148; Ukrasi i simoli na južnovelebitskim mirilima na području Selina (II), Senjski zbornik 10-11, 1984, 5972. Prema Gavazziju (1978) prvo mjesto na kojem se spustilo pokojnika nazivalo se počivalom i tu je bilo i izrađeno mirilo, a dalje do groblja bila su počivala ali bez mirila. Mirilo je manji nadgrobni humak ili bi se izradilo od lijepo obrađenih kamenih ploča. 
su kazivači naveli da se počivala ničim nisu obilježavala. Kazivači su mi pokazali počivalo kraj Cupića, na putu od Alana do Podbila. To mjesto se ni po čemu ne razlikuje niti upućuje na njegovo značenje, no svi kazivači znaju da je tu bilo počivalo. Niti jedan kazivač nije potvrdio da su na ovim područjima postojala mirila, no poneki su naveli da ih imaju Podgorci i da je tamo naslagano kamenje. Na počivalištu je jedna osoba, uglavnom muškarac, molila na glas, a ostali za njim. ${ }^{109}$ Prema navodima kazivača, svećenik nije išao s povorkom od pokojnikove kuće nego ju je sačekao blizu crkve te ostatak puta išao s povorkom i dovršio obred pokapanja.

Sredinom 20. stoljeća na ovim je područjima započelo intenzivno raseljavanje stanovništva. Kazivači navode da su upravo zbog nedostatka muškaraca pokojnike počeli prevoziti na kolima, iz lokaliteta gdje je to bilo moguće zbog konfiguraciji terena. Kolima se moglo prevoziti primjerice iz Šušnja, Vrataruše i Kosove Buljime. Kada je netko umro u Bunici nosili su ga preko Vrataruše, a od Vratruše do Podbila vozili na kolima.

Svi pokojnici iz područja Krivoga Puta pokapani su u Podbilu, no posmrtni običaji bili su različiti. Tako su primjerice kazivači naveli da se nakon pogreba u pojedinim lokalitetima odlazilo pokojnikovoj kući. Prije u Veljunu, Serdarima, Mrzlom Dolu, Šojatskom Dolcu, Francikovcu, Krivom Putu vraćaju se kući i jedu. Na Veljunu peku dva janjeta i tele. Na tu večeru poslije može doć 'ko hoće. Rodbina dode sva a ostali 'ko hoće. Znalo se napit i potuć. A mi tu prema Krmpotama, Alanu, Podbilu, nismo to ništa. ${ }^{110}$ Ovo je samo jedan fragment koji upućuje na kulturološku razliku između geografskog područja na koja su selili Primorci i na kojima je stanovalo isključivo stalno stanovništvo. ${ }^{111}$

Gledajući u širem geografskom kontekstu primjećuje se daljnja posebnost čitavog područja Krivoga Puta, dakle graničnog područja između Velike Kapele i sjevernog Velebita. Naime, pokojnika su iz stalnih (zimskih) naselja nosili na područje gdje su privremeno boravili, dakle na planinu u ljetne stanove. No pojedini su primjerice ljeti boravili na oko 500 do 600 metra nadmorske visine, a zakapali se na oko 800 metara, dakle području na kojem nikad nisu boravili. Prema mojim saznanjima na području velebitskoga Podgorja župne crkve i groblja bile su uz stalna naselja pokraj mora i stoga su pokojnika nosili niz planinu. ${ }^{12}$ No u slučaju Krivoga Puta crkva je bila na planini zato što su ondje bila i stalna naselja.

\section{OD LJETNIH STANOVA DO TRAJNIH NASELJA}

$\mathrm{T}$ ijekom istraživanja i analize dobivenih podataka stalno sam se pitala zašto su neki selili, neki ne i odakle sve ove varijante migracijskih mobilnosti. Odgovori su bili različiti. Neki nisu htjeli tu (u naseljima na oko 800 metara nadmorske visine) živjet. A neće Primorac tu zimi da boravi, on je navikao, neće on tu. ${ }^{113}$ No mnogi kazivači naveli su: Prije su svi selili dole po zimi, ali su po malo radili kuće gore i ostajali živjeti, $i$ tako se po malo ostajalo. ${ }^{114} \mathrm{U}$ nekoliko trajnih naselja, u sjećanjima pojedinaca žive priče o prvim stalnim stanovnicima. U nastavku donosimo naracije kazivača o nastanku Alana, Šušnja, Francikovca te pojedinih zaselaka.

109 Svi stanovnici bili su rimokatoličke vjeroispovijesti. Molio se jedan Oče Naš i jedna Zdravo Marija, Slava Ocu i na kraju kazalo: Preporući njegovu dušu. Bože primi ga. Ako se komu zamerio neka mu oprosti. Oprostite mu ako vam se u svojoj slabosti zamjerio. Zatim su svi prisutni rekli: Neka mu Bog oprosti.

110 Ivan Vukelić Mikula, Petar Tomljanović Čona.

111 Kako tema ovoga rada nisu pogrebni običaji niti kulturološke razlike između ovih prostora, ovim tek želim uputiti na potrebu detaljnijih istraživanja ovih tema.

112 Građa s terenskih istraživanja velebitskog Podgorja bit će korištena u mojoj doktorskoj disertaciji. Podgorci su se iznimno pokapali na planinama za vrijeme epidemija. O ovoj problematici također vidi u: A. Glavičić, 1980: 200 ; M. Marković, 1971, 1980, 2003; V. Belaj, 2004.

113 Anka Šolić Tutanova.

114 Mirko Tomljanović Sova. 
U Alanu na kući Mladena Gare piše 1700. godina. ${ }^{15}$ Zato su oni uzeli najbolju zemlju na Alanu, imaju svu zemlju ispred kuće. To su pričali da je tu doselio jedan oficir. Od njega su se oni razvili poslije. Došli su iz Sibinja i bili su najbogatiji. I moji su tu tako selili jedno vrime iz Krmpota, Vukeljske drage. Moj je djeda roden 1857. godine, on se dole rodio i onda su selili, a kad se vjenčo tu su bili. Tamo dole su imali male kućice, a tu stanove. Onda su se oni posle izminjali, oni su ovima doli dali svoju zemlju doli, a ovi njima svoju zemlju gori. Neki nisu tili selit pa su primili zemlju. Did se ženia negdi 1877., moj je otac bia rođen 1888. Tu negdi su izmijenili. Onda su se ljudi poslije ovdje okućili i više su krčili šume, kazala je Anka Butković Matićeva.

Kazivač Zlatko Tomljanović Kaićn naveo je: Moj je šukundjed prvi iz Primorja doselio u Šušanj iz Sibinja i tu osto živjet. Vjerojatno mu je tu bila zemlja a doli se familija podijelila, bilo ih je puno. Tak su ljudi ostajali u Šušnju, bilo je šest familija koje su tu stalno bile. Ne znam iz kojih su mjesta druge obitelji doselile al tu su bila samo dva pezimena, Tomljanović i Prpić. To su faktički dvi familije bile, mi smo Kaići a oni Pekini (obiteljski nadimci op.a.).

Tomljanović Petar Čona koji danas živi u Podbilu, u zaselku Cupići kazao je: Mi smo iz Cupine. Moji su tu stalno već biće 350 godina. U Cupini je kuća srušena odavno. A ovdje su ostali jel su tu imali šumu i sve, zemlju.

O Francikovcu sam zabilježila sljedeće podatke: Ove zidinice iza kuće (sl. 5), tu je bila glavna familija Šojati (nadimak Juričini, Markišini op.a.). Ta kuća je sagradena prije dvi, tri stotine godina. Tu su se rodili šukundidi, didi, pradidi. Mi smo svi, sve ovo nas petnaest kuća od njih, to je sad već osma, deveta generacija. E, u obiteljima se rodilo po dva tri sina ili više i dijelili se. I sad se gore vide dva kantuna, stijene di su prva dva došli, a treći brat je oša u Šojatski Dolac. Kamenje je ispod Tesline kuće, e tu im je bila prva kuća. ${ }^{16}$ Nakon njih su ljeti selili neki iz Senjske Drage, a poslije dio familije osta ovdi živjeti. Kazivači nisu znali reći kada je to bilo, ali su mi pokazali na jednoj šterni upisanu 1891. godinu (sl. 5a), te na drugoj šterni 1901. godinu. Obje su šterne pripadale tim obiteljima. ${ }^{117}$

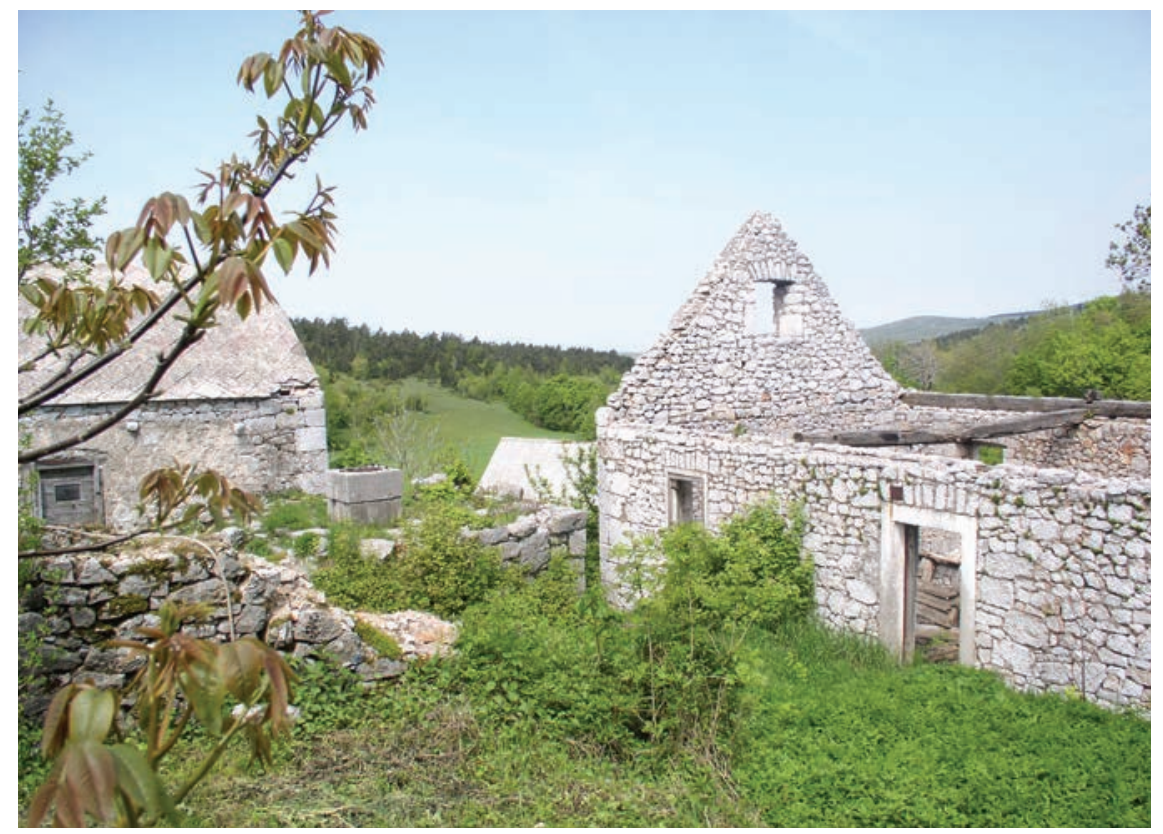

Slika 5: Ostaci stambenih objekata na Francikovou; snimila M. Rajković, lipanj 2005.

115 Iznad ulaznih vrata piše 1765. godina. Njezini vlasnici rekli su da se kuća nekoliko puta adaptirala i da je možda i prije postojao neki objekt (sl. 2).

116 Zamolila sam kazivača da mi pokaže kamenje ne bi li ga fotografirala, no kazao je da nemam što fotografirati budući da je sve zaraslo, a vidi se samo grmlje i obično kamenje. No stanovnici znaju da su to temelji koji su zarasli.

117 Francikovac se sastoji od zaselaka: Matići, Busije, Seljani, Božići, Barišići. Prezimena su Šojat i Prpić. 


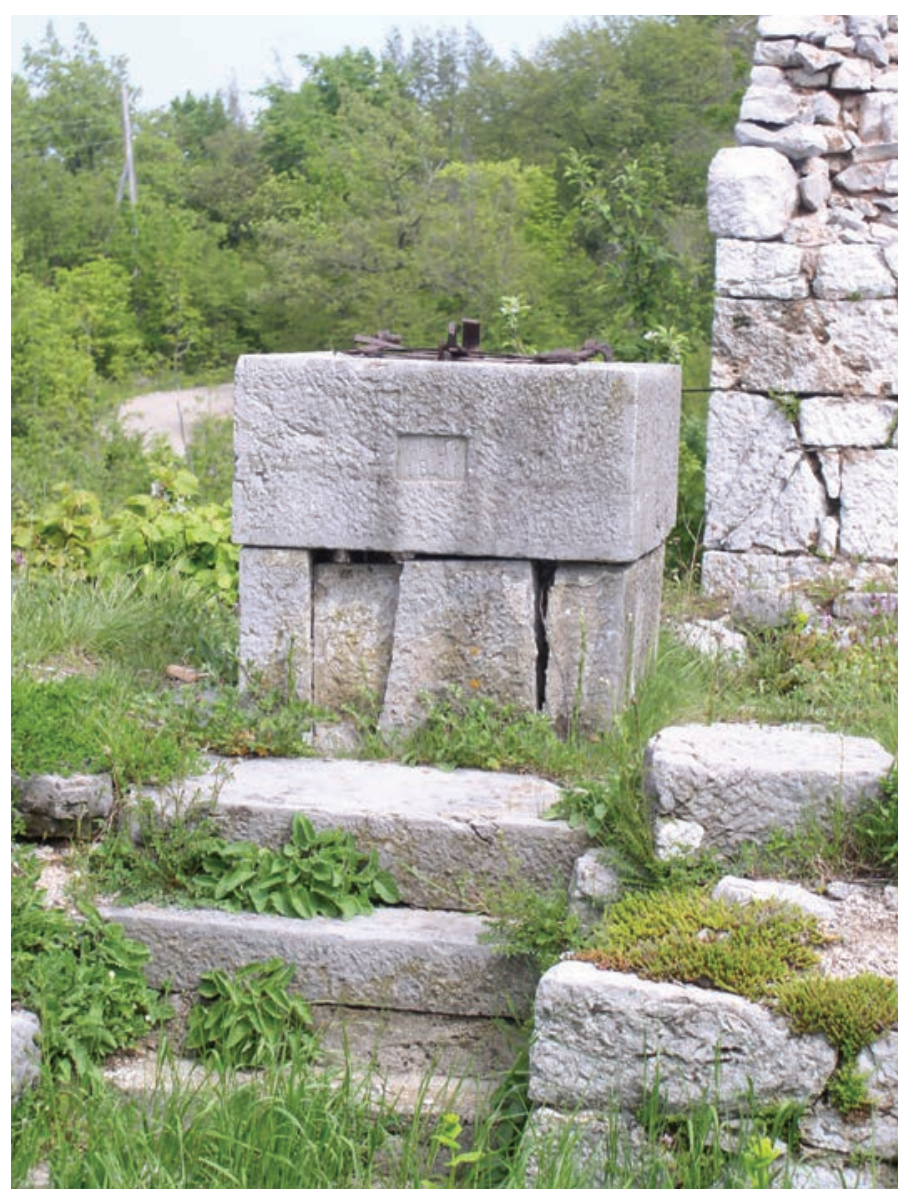

Slika 5a: Šterna s upisanom godinom 1891. iz istog obiteljskog kompleksa.

Za ostale lokalitete kazivači nisu znali navesti tko se i kada prvi nastanio, ali su trajna naseljavanja na ljetne stanove pripisivali nasljeđivanju zemljišta. Tome u pri$\log$ svjedoče naracije Milana Prpića Brkca: Iz Bunice su selili u Vrtlinu, unazad 200 godina. Neki su ostali gori, a neki su selili. Braća bi se podijelila neki gori neki doli, ista prezimena čak i rodbina.

Sklona sam mišljenju da ovih nekoliko zabilježenih primjera ukazuje na višestoljetni proces pretvaranja ljetnih stanova u trajna naselja. Da ova pojava nije jedinstvena, saznajemo i od Ante Glavičića koji piše da stanovnici iz primorja "prelaze liniju današnje magistrale i u srednje visinskim zonama Velebita (do 700 metara nadmorske visine) osnivaju nova naselja u šumovitim i do tada nenaseljenim mjestima. Tako nastaju nova naselja Stolac, Oltari (...) Ledenik, Sušanj.” (Glavičić 1980:200)

Kao što je vidljivo najčešće su na jednom lokalitetu živjeli stanovnici s jednim prezimenom ili tek s nekoliko. Primjerice u Kosovoj Buljimi svi su Prpići, a u Vrataruši Tomljanovići. Na ovim prostorima točno se zna koje su obitelji živjele na kojim lokalitetima: Ovo selo gore su Prpići onda Pijavica tu idu Prpići do Svete Jelene, onda gore ovo selce su Špalji. Onda od Bunice, Vrataruše su Tomljanovići, onda idu Cupine, Sibinj, gore u brdu su Butkovići oni su do Smokvice, tu ima i Butkovića i Blaževića, navela je Mira Ostović. Da slične paralele pronalazimo i u ostalim primorskim područjima ide u prilog istraživanje Mirka Markovića (na žalost autor ne precizira lokalitete): "U udruživanju stanova najvažniji su bili rodbinski i gospodarski momenti. Rodovska veza naročito je dolazila do izražaja kod Primoraca. Oni su i u Primorju živjeli udruženi u svojim zaseocima, koji su se najčešće nazivali prema njihovim rodovskim prezimenima. Takvi rodovski zaseoci imali su i u nadgorju udružene stanove, pa su se i oni najčešće nazivali isto kao i primorska selišta” (Marković 1980:82). Uz obalu, na području Primorja pronalazimo zaselak Špalji, kao i na području Krivoga Puta (na oko 800 metara nadmorske visine).

Ovo upućuje da u daljnjim istraživanjima selidbi na ljetne stanove svakako treba istraživati i narodno/običajno pravo nasljeđivanja ${ }^{118}$ jer smatram da je ono jedno od bitnih pokazatelja potisnih faktora migracija iz nekog kraja ili pak nastavka života na obiteljskom zemljištu. No također upućujem na činjenicu da podaci koji se mogu dobiti usmenim predajama ne sežu dovoljno u prošlost da bismo dobili potrebne spoznaje. Povijesni izvori potvrđuju naseljavanje Bunjevaca na ova planinska područja tijekom 17. stoljeća, ${ }^{119}$ te je za ovakva istraživanja neophodan rad na arhivskim izvorima. No treba imati na umu

\footnotetext{
118 "Pojam "narodno pravo" još između dva rata označava sustav narodnih običaja s normama društvenog reguliranja odnosa u sredinama koje su još uvijek homogenije sadržavale karakteristike po kojima su se izdvajale od građanskih sredina. Seoske društvene grupe, kao zatvorenije cjeline, još uvijek su se samo pokoravale Zakonima, kad je to bilo neophodno, dok su u svom internom životu nastavljale poštivati običaje" (Čulinović- Konstantinović 1984:51)

119 Usporedi s Pavičić 1966:309-382.
} 
da stanovnici ovog područja nisu imali naviku rješavati pravno-imovinske odnose u gruntovnicama i katastarskim uredima. Naime, na terenu sam nailazila na nemali broj priča kako pojedinci žele kupiti atraktivne stare kamene kuće no vlasnički odnosi nisu regulirani. Sami stanovnici ističu da pojedine takve kuće u kojima su njihovi preci generacijama živjeli nisu nikada katastarski prikazane, a pojedini potomci danas vode sporove s Hrvatskim šumama koji su vlasnici zemljišta. Daljnji problem je što su se obitelji uslijed migracijskih mobilnosti čitavo 20. stoljeće, pa i prije raseljavale i na više kontinenata, a da pritom nisu regulirali vlasništvo nad nekretninama i zemljom.

\section{POGLED ETNOLOGA NA LJETNE STANOVE U BUDUĆNOSTI}

$\mathrm{B}$ oraveći na terenu u više navrata tijekom 2003. i 2004. godine, stvarala sam predodžbu o ljetnim stanovima, no nisam ondje bila iz razloga što se do pojedinih lokaliteta može doći isključivo pješice ili tek do ponekih terenskim vozilom. Tijekom istraživanja u lipnju 2005. godine Milan Tomljanović Livak udovoljio je mojoj istraživačkoj znatiželji te kolegici Mariji Brajković i meni bio vodič kroz nekada ljeti gusto naseljena područja. Danas kroz ta područja prolazi makadamska cesta i tek rijetki prolaznici poput lovaca i lovočuvara. Vozili smo se od Alana, preko Šušnja, Kosove Buljime, Vrataruše te izišli na glavnu cestu kod Klaričevca. Kod nekoliko smo stanova zastali, obišli prostore zarasle travom i grmljem. Vidjele smo primjerice Grgaićin stan u kojem ne živi nitko već oko 100 godina, ali na koji njegov potomak ponekad ljeti seli pčele iz Senja.

Po dolasku u Šušanj kazivač je naveo da je odavde vodila kozja staza do mora (dakle primorskih naselja). Danas u Šušnju ne živi nitko osim što Zlatko Tomljanović Kaić iz Senja ovdje ljeti seli pčele. Nastavili smo put prema Vrataruši i u daljini vidjeli velike štale u kojima najveći uzgajivač ovaca iz Matića danas drži ovce. U Vrataruši danas živi jedini stanovnik - Ivan Tomljanović Roka. Radni vijek proveo je na privremenim radovima, a odlaskom u mirovinu vratio se u rodno selo. ${ }^{120} \mathrm{U}$ Vratarušu ljeti dolaze vikendaši iz Karlovca, Senja i Zagreba. Najčešće ovdje provedu tek vikend ili više dana kada su na godišnjem odmoru ili u mirovini. Milan Tomljanović Livak cijelim putem nam je kazivao o životu na ljetnim stanovima te zaključio da ljudi zadnjih godina dolaze sve više. Šteta im je to zapustit. Ljudi što su stariji to ih valjda sve više vuće neka nostalgija za tim rodnim krajem. I njegov djed je imao ljetni stan na Vrataruši, no kako je bio u ruševnom stanju srušili su ga. Trenutno na istom mjestu, i kako ističe u istom stilu, njegova sestra,

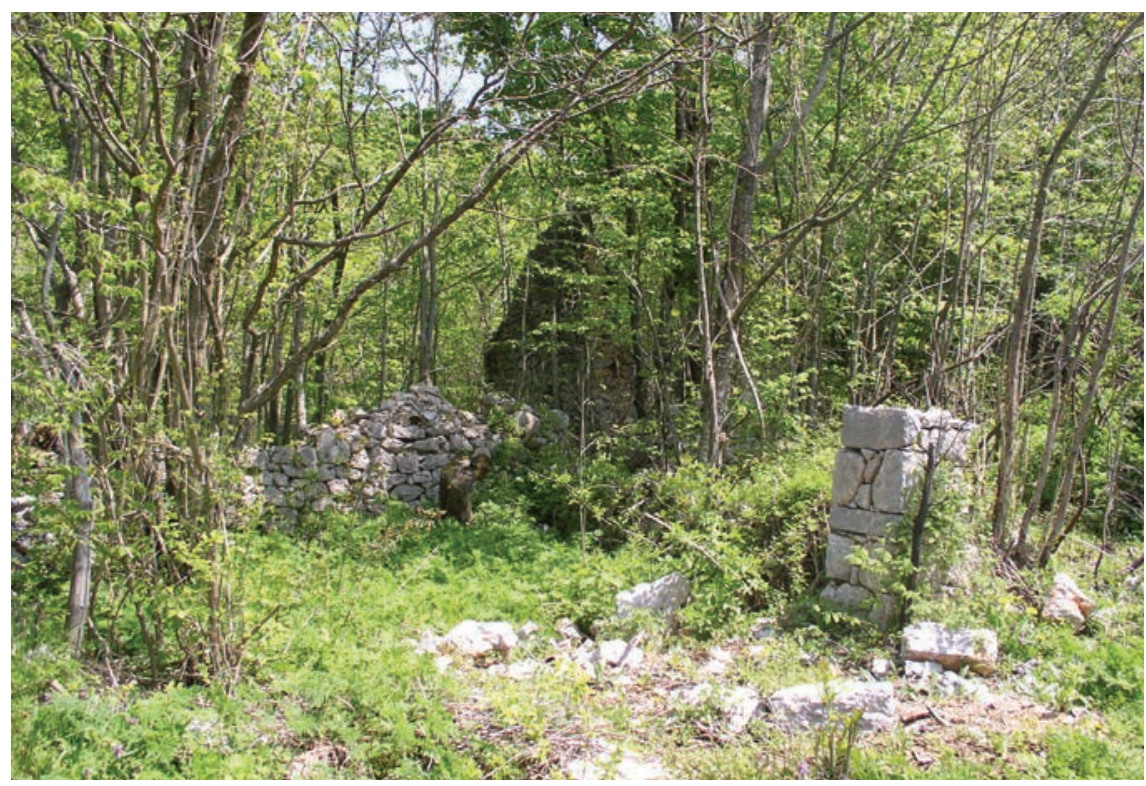

Slika 6: Ostaci ljetnog stana, vlasnike nepoznat; snimila M. Rajković, lipanj 2005. godine.

120 Nažalost nismo mogli razgovarati s njim jer nije bio kod kuće. 
koja živi u Njemačkoj, i on grade kuću od kamena. U Butković Dolcu danas nema stanovnika, samo nekolicina ljudi povremeno dolazi obići djedovinu. Kroz Butković Dolac nekada je vodila cesta iz Alana, preko Vodne Drage na Sibinj. Od Vodne Drage do Sibinja nema ceste već samo kozja staza. U Sv. Jeleni danas živi samo jedan muškarac, te poneki stanovnici koji dođu ljeti na odmor u obnovljene kuće. Iznad Sv. Jelene u Špaljima danas također živi samo jedan stariji muškarac. No vozeći najčešće smo nailazili na ostatke zapuštenih ljetnih stanova. (sl. 6)

Vozeći se po makadamskoj cesti u daljini smo na planini naišli na poslagano kamenje polukružnog oblika, nekadašnju pastirnicu. Visina pastirnice bila je do 1,5 metar, sagrađena je tehnikom suhozida, kamenje je slagano u krug, otvor se radio s južne strane budući da odatle bura nikad ne puše, kazao je Milan Tomljanović Livak. Takve zaklone radio je jedan pastir za sebe ili više njih zajedno.

$\mathrm{Na}$ ovim padinama ima prekrasnih starih kamenih kuća koje su čitave i u kojima bi se moglo stanovat. Danas su prazne, jedino dođe neko malo provjetrit, dodao je isti kazivač. Za sada ove prirodne resurse prepoznaju potomci koji na vlastitu inicijativu obnavljaju stare kuće. Razlog njihova ljetnog boravka zrcali se u kazivanju Anke Šolić Tutanove: Ljeti dolaze obradivati zemlju. Oni su otišli odavle 60, 70-ih ponapravili kuće u Senju i sad tu dolaze obradivat zemlju. Možda je neko - neko zapustio zemlju ali uvijek neko dolazi. Uvijek su obradivali. Sad sve česće obnavljaju kuće, kad su stari lipo im je ovdje. Imaju svi aute pa im nije teško spustit se u Senj (koji je udaljen svega 14 kilometara op.a.).

Jedna od mnogih osoba koja ljeti često boravi u Alanu je i Milan Tomljanović Periša. Otkako sam u mirovini sad me nekako nostalgija vuće, često sam gore svakog vikenda, i ljeti, $i$ sad je tamo šuma narasla a napravim i nešto drva za familiju. Onda sam par godina sadio malo krumpira. No sigurna sam da bi i ljudi koji nisu porijeklom odavde voljeli doći i uživati u ovim prekrasnim planinama. Upravo stoga sam ovim odlomkom željela tek ukazati na ulogu etnologa i ponajviše na mogućnost primjenjivanja etnoloških istraživanja u revitalizaciji ovoga depopuliranoga $\mathrm{kraja}^{121}$, te tu ukazati na prepoznatljivost uloge ljetnih stanova kroz oblike ruralnog turizma, a kroz to i, nadam se, budućoj turističkoj ponudi ovoga kraja.

\section{ZAKLJUČNA RAZMATRANJA}

$\mathrm{I}$ stražujući tradicijsko gospodarstvo, tema sezonskih migracija nametnula se kao neophodna za istraživanje istoga te za razumijevanja načina tradicijskoga života i kulture. Iz primorskog pojasa stanovništvo je u proljeće selilo prema planinskim pašnjacima na primorskoj strani Velike Kapele. Primjerice iz Sv. Ilije, Sibinja, Cupine, Bunice, Špalja, Sv. Jelene te Pijavice stanovništvo je u proljeće selilo prema planinskim pašnjacima na primorskoj strani Velike Kapele na područja oko 500 do 600 metara nadmorske visine (primjerice: Šušanj, Kosova Buljima, Vrataruša). U jesen su sve selili u Primorje gdje su provodili vrijeme do proljeća. No ovo je područje specifično po tome što su na višim nadmorskim visinama (već spomenuti Šušanj, Vrataruša, Kosova Buljima) već živjeli stalni stanovnici, koji su se katkada selili na još više nadmorske visine na oko 800 do 900 metara (Alan, Podbilo, Krivi Put). Osim njih su na te iste visine selili i pojedini Primorci. Tijekom 20. stoljeća seobe su ovisile od obitelji do obitelji, tako da su neki selili na jednu etapu (s prve na drugu ili s prve na treću), a neki na dvije (s prve na drugu, pa s druge na treću), dok neki uopće nisu selili, odnosno stalno su stanovali na drugoj ili trećoj etapi. Razlozi njihova seljenja bile su ispaše blaga (goveda, ovce, koze), ali i uzgoj svinja, obrađivanje zemlje (motičarstvo), prikupljanje sijena te ispaša pčela. U jesen su sve selili u Primorje gdje su provodili vrijeme do proljeća. Svrha ovoga rada bila je deskriptivno prikazati sezonske migracije na mikro lokalitetu Krivoga Puta, odnosno utjecaj migracijskih mobilnosti na sveukupni način života. Istraživala sam potisne i privlačne faktore migracija, život na ljetnim stanovima (nastambe), interakcijske odnose između migratornog stanovništva (Primoraca) i domicilnog stanovništva (stalnih stanovnika viših nadmorskih visina).

121 Više o ovoj temi vidi u radu M. Černelić i M. Rajković (2007): Mogućnosti revitalizacije tradicijske baštine na području Krivoga Puta u senjskom zaleđu, Studia ethnologica Croatica, vol. 19, str. 245-268. 
Ako pokušamo rekonstruirati migracijska kretanja jedne obitelji koja je zimi stanovala u Sibinju, a ljeti selila u Šušanj, dolazimo do saznanja da su djeca išla u školu u Vratarušu (neovisno o tome gdje su stanovala), žene su rano ujutro nosile mlijeko u Senj (svaki dan ili svaki drugi), nedjeljom je čitava obitelj išla na bogoslužje u Podbilo (gdje su se uostalom i pokapali), a prema potrebi silazili su u Sibinj nositi ljetinu za zimske periode. Muški članovi obitelji nerijetko su odlazili na sezonske i privremene radove u druge udaljenije krajeve, te se vraćali kući za vrijeme sjenokoše. Tijekom sjenokoše boravili su nekoliko dana u udaljenijim lokalitetima na području Krivoga Puta u priručnim nastambama, a žene su im nekoliko puta dnevno nosile hranu. Prilikom razmišljanja o prelascima ovih dnevnih udaljenosti ne smijemo zaboraviti činjenicu da su se kretanja odvijala pješice tzv. kozjim stazama, a glavna transportna sredstava bili su magarci i/ili mule.

Ovakav način života, prakticiran do šezdesetih godina 20. stoljeća, koji sam nadam se uspjela dubinski istražiti i ocrtati čitatelju, ukazuje na potrebu dubljih kronoloških istraživanja. Naime, nameće mi se pitanje, zašto su stanovnici ovih područja izabrali ovakav način života, s tolikom varijantom migracijske mobilnosti. Iz današnje perspektive to je teško objasniti. Upravo iz tih razloga dotakla sam se teme formiranja trajnih naselja na ljetnim stanovima (time nikako ne smatram da su sva trajna naselja na području Krivoga Puta nastala iz sezonskih naselja, primjerice u Mrzli Dol i Veljun nitko nije selio). Selidbe Krivopućana navode me na usporedbu s alpskim tipom stočarstva. Naime, ovako sakupljena građa može poslužiti za razne etnološke spoznaje. Primjerice, pomoću raznih tipova stočarstva možemo iščitavati kulturnopovijesne veze te eventualno podrijetlo svakog od njih. Dakako da treba uzeti u obzir da se način života oblikuje prema geografskim uvjetima terena i lokalnim običajima, stoga se i načini iskorištavanja planine realiziraju u raznim inačicama, no u pravilu treba izdvojiti osnovne crte, koje bi trebale biti posvuda jednake.

$\mathrm{Na}$ važnost ovakvih istraživanja ukazuje i etnolog Vitomir Belaj "Sučeljavajući (alpsko stočarstvo, op.a.) s tipičnim transhumantnim stočarstvom koje do najnovijeg doba prevladava na planinama balkanskog poluotoka, pokazuje na mogućnost otkrivanja kulturnopovijesnih procesa u kojima je neko staro, po podrijetlu predindoeuropsko, stanovništvo sa svojim specifičnim načinom života sudjelovalo u nastajanju etničke skupine poznate pod imenom Bunjevci” (Belaj, 2004:5).

Za neupućena čitatelja ukratko ću objasniti razlike u značajkama pojedinog tipa stočarstva. "Osnovna značajka transhumantnog stočarenja jest da su vlasnici stada (u pravilu je riječ o ovcama) nastanjeni u stalnim naseljima gdje se bave skromnom zemljoradnjom, dok su sama stada i ljeti i zimi na pašnjacima gdje ih čuvaju pastiri. Ovo potonje bilo je uvjetovano činjenicom da pojedini vlasnici stada sve donedavno nisu prikupljali krmu (sijeno) za zimu, pa je stoka morala zimi tražiti pašu u toplijim krajevima uz more" (Ibid. 9).

Bitne značajke alpskog stočarstva su da je zimi cijela obitelj zajedno sa stokom u matičnom selu i stoku krme sijenom. U proljeće se odvija izdig cijelog sela zajedno sa stokom. Ondje obrađuju vrtove (motičarstvo) i nerijetko njive, te prikupljaju sijeno za zimu. U visoko ljeto (srpanj, kolovoz), dok obitelj i dalje živi i radi u ljetnom stanu, pastiri odlaze sa stokom na planinu tj. na visoke pašnjake gdje imaju stanove i kolibe za spravljane sira. Alpski stočari uzgajaju prvenstveno goveda, a u znatno manjoj mjeri još i koze i svinje. U jesen pastiri se sa stokom vraćaju na majska selišta. Nakon toga svi se spremaju za silazak u donje, zimsko selo i sobom nose plodine i sjeno za krmu.

Vitomir Belaj komparira alpsko stočarstvo sa stočarstvom Podgoraca: "Imali su u pravilu tri stalne naseobine: jednu (zimsko selo) blizu mora, drugu (selo nastanjeno od proljeća do jeseni, gdje su obrađivali njive i prikupljali sijeno) na podima na oko 800 m nadmorske visine, a treću pod vrhovima Velebita (ljetni stan, samo za pastire)" (Ibid. 13).

Autor navodi da u literaturi nije navedeno je li planinsko stočarstvo bilo dopunski dio u tradicijskom gospodarstvu ili njegov glavni i jedini dio. I Podgorci na planini siju žitarice i sade krumpir i kose travu, dakle ne ponašaju se kao transhumantni stočari.

Usporedimo sada sve navedeno s ljetnim seobama Primoraca, Krivopućana. Dakle, zimska sela su u Primorju. U proljeće cijele obitelji (ili veći dio) sele s kućanskim predmetima, blagom, košnicama. No 
ne seli čitavo selo zajedno, niti na isti lokalitet. Selidbe su trajale od nekoliko dana do nekoliko tjedana, a pojedini članovi dolaze tek za potrebe većih gospodarskih radova. Velika se pažnja posvećivala sjenokoši (koja je bila vrlo važna zbog prehrane domaćih životinja zimi). Stoga su muški članovi obitelji koji su odlazili na privremene radove u ostale dijelove Hrvatske ili zapadnu Europu uzimali u to vrijeme godišnje odmore i dolazili pomagati kositi sijeno. ${ }^{122}$ Dakle, paralelno su gradili pojate (skloništa) na udaljenijim područjima gdje su imali livade koje su kosili, no one nisu nužno bile na višim nadmorskim visinama. $U$ tim nastambama boravili su kosci za vrijeme košnje (nekoliko dana).

Usporedimo sada život na području Krivoga Puta s alpskim tipom stočarstva. Ovi stanovnici imali su dvije stalne naseobine. Na planinskim pašnjacima migratorno stanovništvo obrađivalo je njive (također motikama), sjenokoša je imala važnu ulogu, a prevladavala su goveda, manji broj ovaca, svinje. Nema odlazaka pastira na visoke pašnjake (stoka nikada ne boravi u torovima, već isključivo u štalama), ali ljudi tamo borave privremeno (nekoliko dana) radi sjenokoše ili drugih radova vezanih uz zemljoradnju.

No postavlja se pitanje zašto neki sele na 500 do 600 metara nadmorske visine, a neki na 800 metara. Kazivači ističu da su uvijek (barem u razdoblju prve polovice 20. stoljeća) selili na vlastitu zemlju. Jesu li možda u prošlosti (od nekoliko stoljeća) selili na tri etape, no zbog brojnih obitelji (jer svi su imali mnogo djece) i običajnog prava nasljeđivanja, ponajviše da je svako muško dijete dobivalo dio zemlje, naselja su postala i trajna i privremena pa su neki selili a neki nisu, dok su pojedini samo odlazili obrađivati zemlju, ostaje pitanje kojim bi se trebala baviti neka mnogo sustavnija istraživanja.

Kretanja stanovnika na mikro ekosustavu Krivoga Puta razlikuje se od opisa koje sam dosada susretala u starijoj literaturi i izvorima. Na geografskom području koje pokrivam ovim radom, prema mojim saznanjima, do sada nitko nije istraživao selidbe na ljetne stanove. Prilikom nestrukturiranih intervjua, odnosno rekognisciranja terena za pripremu upitnice za temu migracija došla sam do spoznaje da migracije stanovništva nisu bile isključivo izdizi stoke i da bih dobila vrlo upitne podatke ograničivši istraživanje samo na tu problematiku. Za susjedna područja, područje sjevernog Velebita, u starijoj etnološkoj i antropogeografskoj literaturi te seobe opisane su ponajviše kao izdizi stoke na ljetne stanove. Primjerice antropogeograf i planinar Mirko Marković u tekstovima (Stočarska kretanja na dinarskim planinama, 1971.; Narodni život i običaji sezonskih stočara na Velebitu, 1980.) ne navodi izvore, te ih se ne može provjeravati, rijetko su prostorno točno locirani, stoga ne znamo na koje lokalitete se odnose. Osim toga nisu ni kronološki određeni. Njegovi nam podaci mogu poslužiti za osnovnu orijentaciju, ali ne i za konkretnu komparaciju. Međutim, istražujući susjedna područja, točnije područje Senjskog bila, Krmpota (zaleđe Novog Vinodolskog), područje sjevernog i srednjeg velebitskog Podgorja došla sam do saznanja da su se i oni na ljetnim stanovima bavili zemljoradnjom i košnjom trave, seobe su bile na dvije ili tri etape, negdje nisu selili, no daljnja analiza bit će prikazana u narednim radovima.

\section{LITERATURA:}

BELAJ, Vitomir (2004): Tradicijsko planinsko stočarstvo na Velebitu i bunjevačka etnogeneza. Studia ethnologica Croatica, 16:5-31.

BIRT, Danijela (2004): Transport i opskrba vodom na području Krivog Puta, Senjski zbornik 31:159 188.

ČAPO, Jasna (1988): Etnologija između demografije i socijalne historije. Etnoloska tribina 11:5-16.

ČULINOVIĆ-KONSTANTINOVIĆ, Vesna (1984): Običajno pravo, njegova primjena i proučavanje do polovine 20. stoljeća. Etnološk tribina 6-7:51-70.

Moje terenske bilješke i usporedi V. Belaj, 2004:14. 
GAVAZZI, Milovan (1978): Počivala. U: Vrela i sudbine narodnih tradicija, Sveučilišna naklada Liber, Zagreb 1978, 197-205.

GLAVIČIĆ, Ante (1980): Mirila i počivala na Velebitu (I), Senjski zbornik 8, 1980, 197-210.

HERŠAK, Emil (ur.) (1998): Leksikon migracijskog i etničkog nazivlja. Institut za migracije i narodnosti, Školska knjiga, Zagreb.

KORENČIĆ, Mirko (1979): Naselja i stanovništvo Sr Hrvatske 1857-1971, Zagreb, 603 - 607.

MARKOVIĆ, Mirko (1971): Stočarska kretanja na dinarskim planinama. U: Zbornik za narodni život $i$ običaje, 45:523-550.

MARKOVIĆ, Mirko (1980): Narodni život i običaji sezonskih stočara na Velebitu. U: Zbornik za narodni život i običaje, 48:5-140.

MARKOVIĆ, Mirko (2003): Stočarska kretanja na dinarskim pašnjacima. Naklada Jesenski i Turk, Zagreb.

PAVIČIĆ, Stjepan (1966): Prilozi nepoznatoj povijesti grada Senja i okolice. Senjski zbornik, 2:309-382.

RAGUŽ, Mirko (1990): Osnovna škola Krivi Put, Senjski zbornik 26:343-360.

RAJKOVIĆ, Marijeta (2003): Život žene u selima Senjskog bila. Senjski zbornik, 30:539-586.

RAJKOVIĆ, Marijeta (2004): Prilozi poznavanju migracija Krivopućana, Senjski zbornik 31:261-286.

RUBIĆ, Tihana (2004): Trgovina i sajmovi, rezultati istraživanja na području općine Krivi Put. Senjski zbornik, 31:287-324.

ŽIVKOVIĆ, Ilija; ŠPORER, Željka; SEKULIĆ, Duško (1995): Asimilacija i identitet. Školska knjiga, Zagreb. 